\title{
Polar stratospheric cloud evolution and chlorine activation measured by CALIPSO and MLS, and modeled by ATLAS
}

\author{
Hideaki Nakajima ${ }^{1,2, a}$, Ingo Wohltmann ${ }^{2}$, Tobias Wegner ${ }^{3}$, Masanori Takeda ${ }^{4}$, Michael C. Pitts ${ }^{3}$, Lamont R. Poole ${ }^{5}$, \\ Ralph Lehmann ${ }^{2}$, Michelle L. Santee ${ }^{6}$, and Markus Rex ${ }^{2}$ \\ ${ }^{1}$ National Institute for Environmental Studies, Tsukuba, 305-8506, Japan \\ ${ }^{2}$ Alfred Wegener Institute for Polar and Marine Research, 14473 Potsdam, Germany \\ ${ }^{3}$ NASA Langley Research Center, Hampton, Virginia 23681, USA \\ ${ }^{4}$ Graduate School of Tohoku University, Sendai, 980-8579, Japan \\ ${ }^{5}$ Science Systems and Applications, Incorporated, Hampton, Virginia 23666, USA \\ ${ }^{6}$ Jet Propulsion Laboratory, California Institute of Technology, Pasadena, California 91109, USA \\ anow at: Council for Science, Technology and Innovation, Cabinet Office, Government of Japan, Tokyo, 100-8914, Japan
}

Correspondence to: Hideaki Nakajima (nakajima@nies.go.jp)

Received: 23 June 2015 - Published in Atmos. Chem. Phys. Discuss.: 18 August 2015

Revised: 1 February 2016 - Accepted: 12 February 2016 - Published: 14 March 2016

\begin{abstract}
We examined observations of polar stratospheric clouds (PSCs) by CALIPSO, and of $\mathrm{HCl}$ and $\mathrm{ClO}$ by MLS along air mass trajectories, to investigate the dependence of the inferred PSC composition on the temperature history of the air parcels and the dependence of the level of chlorine activation on PSC composition. Several case studies based on individual trajectories from the Arctic winter 2009/2010 were conducted, with the trajectories chosen such that the first processing of the air mass by PSCs in this winter occurred on the trajectory. Transitions of PSC composition classes were observed to be highly dependent on the temperature history. In cases of a gradual temperature decrease, nitric acid trihydrate (NAT) and super-cooled ternary solution (STS) mixture clouds were observed. In cases of rapid temperature decrease, STS clouds were first observed, followed by NAT/STS mixture clouds. When temperatures dropped below the frost point, ice clouds formed and then transformed into NAT/STS mixture clouds when temperature increased above the frost point. The threshold temperature for rapid chlorine activation on PSCs is approximately $4 \mathrm{~K}$ below the NAT existence temperature, $T_{\mathrm{NAT}}$. Furthermore, simulations of the ATLAS chemistry and transport box model along the trajectories were used to corroborate the measurements and show good agreement with the observations. Rapid chlorine activation was observed when an air mass encountered PSCs. Usually, chlorine activation was limited by the amount of
\end{abstract}

available $\mathrm{ClONO}_{2}$. Where $\mathrm{ClONO}_{2}$ was not the limiting factor, a large dependence on temperature was evident.

\section{Introduction}

Soon after the discovery of the Antarctic "ozone hole" (Farman et al., 1985), it was established that heterogeneous reactions on polar stratospheric clouds (PSCs) play an important role in ozone destruction (Solomon et al., 1986, 2015; Portmann et al., 1996). They are the first step in the conversion of chlorine reservoir species $\left(\mathrm{ClONO}_{2}\right.$ and $\left.\mathrm{HCl}\right)$ to highly reactive radical species $(\mathrm{Cl}, \mathrm{ClO})$ which drive catalytic cycles that destroy ozone (e.g., Molina and Molina, 1987).

PSC particles may be solid, consisting of ice (cf. the historical overview by Peter and Grooß, 2012) or nitric acid trihydrate (NAT: $\mathrm{HNO}_{3} \cdot 3 \mathrm{H}_{2} \mathrm{O}$ ) (Crutzen and Arnold, 1986; Voigt et al., 2000). Alternatively, they may also be liquid $\mathrm{H}_{2} \mathrm{O}-\mathrm{H}_{2} \mathrm{SO}_{4}-\mathrm{HNO}_{3}$ droplets (super-cooled ternary solution $=$ STS) (Carslaw et al., 1994). Liquid and solid particles can coexist over a wide range of conditions (Koop et al., 1997; Pitts et al., 2009).

The mechanisms by which NAT particles are formed have provoked some controversy (for a review, see Peter and Grooß, 2012). Laboratory measurements have shown that homogeneous nucleation of NAT in $\mathrm{H}_{2} \mathrm{O}-\mathrm{H}_{2} \mathrm{SO}_{4}-\mathrm{HNO}_{3}$ solu- 
tions is kinetically limited, and thus cannot be expected immediately after the existence temperature of NAT $\left(T_{\mathrm{NAT}} \approx\right.$ $195 \mathrm{~K}$ in the lower stratosphere) is reached (Koop et al., 1995). Another proposed NAT formation mechanism is heterogeneous nucleation on ice particles (Koop et al., 1995), which requires temperatures below the ice frost point $\left(T_{\text {ice }} \approx\right.$ $188 \mathrm{~K}$ in the lower stratosphere). However, NAT PSCs have been observed by both in situ aircraft and satellite measurements in air masses that had not been exposed to temperatures below $T_{\text {ice }}$ (e.g., Pagan et al., 2004; Larsen et al., 2004; Voigt et al., 2005; Pitts et al., 2011). Therefore, heterogeneous nucleation of NAT on meteoritic dust has been considered as an alternative "fast track" to NAT formation at temperatures above the frost point (Voigt et al., 2005; Hoyle et al., 2013), contrary to Biermann et al. (1996) who showed in laboratory experiments that heterogeneous nucleation rates on micrometeorites are too low to enhance freezing of PSCs above the frost point.

The uptake of chemical species, e.g., HCl, by PSC particles and the subsequent heterogeneous reaction rates depend on PSC particle composition and surface area density (and hence strongly on temperature). Chlorine reservoir species are converted into active chlorine species by heterogeneous reactions on the surface of PSCs through

$\mathrm{ClONO}_{2}+\mathrm{HCl} \rightarrow \mathrm{HNO}_{3}+\mathrm{Cl}_{2}$,

$\mathrm{ClONO}_{2}+\mathrm{H}_{2} \mathrm{O} \rightarrow \mathrm{HNO}_{3}+\mathrm{HOCl}$,

$\mathrm{HOCl}+\mathrm{H}_{2} \mathrm{O} \rightarrow \mathrm{Cl}_{2}+\mathrm{H}_{2} \mathrm{O}$.

Although chlorine activation on PSCs is an essential step towards ozone depletion, under certain conditions the ozone loss may be rather insensitive to the rate constants of those heterogeneous reactions and thus to the composition of PSCs present (e.g., Drdla and Schoeberl, 2003; Wohltmann et al., 2013). For instance, this sensitivity is expected to be small if the PSCs exist long enough so that one reaction partner of a heterogeneous reaction becomes almost completely depleted. It is also small if one of the reaction partners has already been depleted and its regeneration by gas-phase chemistry is slower than the heterogeneous reactions.

According to the above-mentioned findings, the following questions are relevant for understanding ozone depletion:

1. Which PSC compositions form under which conditions?

2. How sensitively does chlorine activation depend on PSC composition?

In order to investigate question 1 , we used PSC observations by the CALIOP (Cloud-Aerosol Lidar with Orthogonal Polarization) instrument on the CALIPSO (CloudAerosol Lidar and Infrared Pathfinder Satellite Observations) satellite in the Arctic winter 2009/2010 and temperature data from ECMWF (European Centre for Medium-Range Weather Forecasts) analyses on backward trajectories initiated at the locations of the PSC observations. All three PSC compositions mentioned above (STS, NAT, ice) were observed. These analyses show that the PSC particle composition depends not only on the temperature at the time of the observation but also on the temperature history of the air parcel. This conclusion is in agreement with the findings of Lambert et al. (2012), who used a similar approach with CALIOP PSC composition and Aura Microwave Limb Sounder (MLS) $\mathrm{HNO}_{3}$ data to analyze PSC and $\mathrm{HNO}_{3}$ evolution.

In order to study question 2, we investigated the temporal evolution of $\mathrm{HCl}$ in the vicinity of observed PSCs. For this, we calculated backward and forward trajectories from the positions of the CALIOP PSC observations and considered Aura MLS $\mathrm{HCl}$ measurements within a certain distance ("Match radius") from those trajectories. The signature of chlorine activation seen in the $\mathrm{HCl}$ data was compared to simulations from the Lagrangian chemistry-transport model ATLAS (Wohltmann et al., 2010).

We concentrated on the time period of the first occurrence of PSCs during the winter (mid-December 2009-beginning of January 2010). This choice allowed us to rule out the prior existence of PSCs and associated repartitioning of chlorinecontaining species by heterogeneous reactions. This winter was one of the coldest winters in the Arctic during the CALIPSO operation period when ice PSC was observed by the CALIOP measurements.

\section{Data}

\subsection{CALIPSO/CALIOP PSC data}

CALIPSO, a component of the A-train satellite constellation (Winker et al., 2007, 2009), was launched in April 2006 into a $98.2^{\circ}$ inclination orbit that provides extensive daily measurement coverage over the polar regions of both hemispheres up to $82^{\circ}$ in latitude. CALIOP, the primary instrument on CALIPSO, measures backscatter at wavelengths of 1064 and $532 \mathrm{~nm}$, with the $532 \mathrm{~nm}$ signal separated into orthogonal polarization components parallel and perpendicular to the polarization plane of the outgoing laser beam.

Pitts et al. (2007, 2009, 2011) developed a procedure for detecting PSCs using the CALIOP $532 \mathrm{~nm}$ scattering ratio $\left(R_{532}\right.$, the ratio of total to molecular backscatter) and the $532 \mathrm{~nm}$ perpendicular backscatter coefficient. They further developed an algorithm to classify PSCs by composition based on the measured CALIOP aerosol depolarization ratio $\left(\delta_{\text {aerosol }}\right.$, the ratio of perpendicular to parallel components of aerosol backscatter) and inverse scattering ratio $\left(1 / R_{532}\right)$. Pitts et al. (2009) defined four composition classes of PSCs, i.e., STS, ice, Mix 1, and Mix 2. Mix 1 and Mix 2 denote mixtures of liquid droplets with NAT particles in lower or higher number densities/volumes, respectively. Pitts et al. (2011) added two additional subclasses of PSCs, i.e., Mix 2 enhanced and wave ice PSCs. 
In this study, we used three categories of PSCs from CALIOP data: STS, Mix (which includes Mix 1, Mix 2, and Mix 2 enhanced), and ice (which includes ice and wave ice) PSCs.

In order to assign PSC composition along the trajectories, we selected the composition of the CALIOP measurement location that was closest to each trajectory point on the same day. For each trajectory point, the horizontally closest CALIOP measurement profile was first determined and then the PSC classification closest in potential temperature to the trajectory point was taken from this measurement profile. An analogous method was used to produce the maps in Fig. 2.

Due to the sampling pattern of CALIOP, there is some intrinsic and unavoidable uncertainty in the PSC characterizations at any given location, which is typically some distance away from the point being measured by CALIOP. The approach we have used relies on the assumption that PSCs are sufficiently homogeneous on a spatial scale that corresponds to the average distance to the next measurement, which is about $100-200 \mathrm{~km}$, and a time difference within $24 \mathrm{~h}$.

\subsection{MLS data}

This study also uses data from the Microwave Limb Sounder (MLS) instrument on the Aura satellite (Waters et al., 2006). The Earth Observing System (EOS) Aura satellite was launched on 15 July 2004 and has been in operation since August 2004 making measurements between $82^{\circ} \mathrm{N}$ and $82^{\circ} \mathrm{S}$. MLS measures millimeter- and submillimeter-wave thermal emission from the limb of Earth's atmosphere. We use MLS version $3.3 \mathrm{HCl}, \mathrm{ClO}, \mathrm{O}_{3}$, and $\mathrm{H}_{2} \mathrm{O}$ data (Livesey et al., 2006, 2013). Vertical resolution of MLS data is $\sim 3 \mathrm{~km}$ in the lower stratosphere at $100-10 \mathrm{hPa}$. A discussion of the quality of MLS measurements can be found in Livesey et al. (2013). Error bars in the figures that follow indicate the $1 \sigma$ precision of the measurements.

\section{Analysis method}

\subsection{PSC evolution in the northern winter 2009/2010}

In the Arctic winter 2009/2010, PSCs started to appear in mid-December 2009 at around $23 \mathrm{~km}$ when the minimum temperature dropped below the nitric acid trihydrate saturation temperature $T_{\mathrm{NAT}}$ (Pitts et al., 2011). Figure 1 shows the temporal variation of the minimum temperature $\left(T_{\mathrm{MIN}}\right)$ between 50 and $90^{\circ} \mathrm{N}$ at the $30 \mathrm{hPa}$ pressure level. The two green lines show the NAT and ice PSC threshold temperatures ( $T_{\mathrm{NAT}}$ and $T_{\text {ice }}$, respectively) calculated by assuming $6 \mathrm{ppbv}$ of $\mathrm{HNO}_{3}$ and $4.5 \mathrm{ppmv}$ of $\mathrm{H}_{2} \mathrm{O}$. $T_{\mathrm{MIN}}$ dropped below $T_{\mathrm{NAT}}$ in the middle of December and below $T_{\text {ice }}$ at the end of December 2009 and again in mid-January. A sudden stratospheric warming terminated the period with temperatures below $T_{\mathrm{NAT}}$ at the end of January 2010 (Dörnbrack et al., 2012).

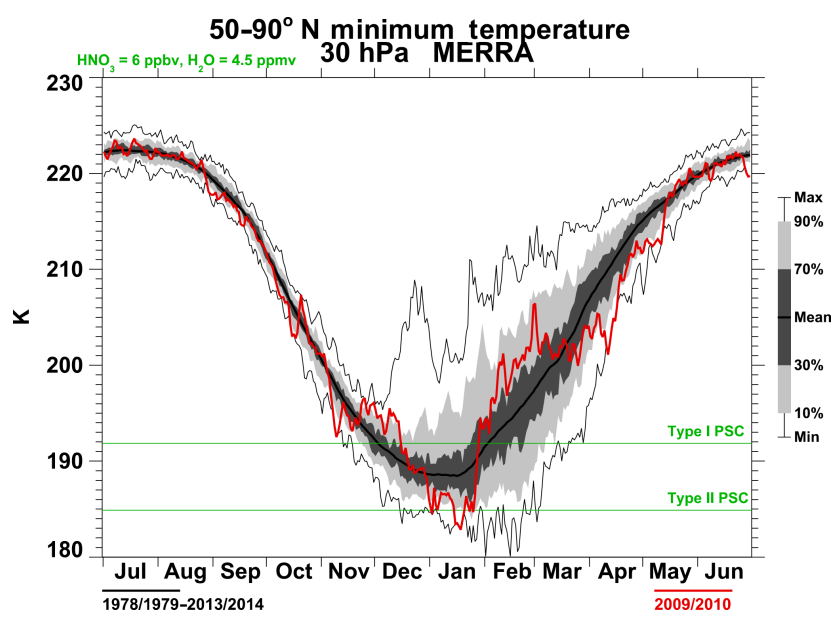

Figure 1. Variation of the minimum temperature $\left(50-90^{\circ} \mathrm{N}\right)$ in the Arctic stratosphere at $30 \mathrm{hPa}$ by Modern-Era Retrospective analysis for Research and Applications (MERRA) data. The thick black line shows the average minimum temperature between 1978/79 and 2013/14, while the thick and thin shaded area represents 30-70 and 10-90\% percentile distributions, respectively. The red line shows the minimum temperature in the 2009/2010 Arctic winter. Two horizontal green lines represent the Type I (NAT) PSC threshold temperature assuming 6 ppbv $\mathrm{HNO}_{3}$ and $4.5 \mathrm{ppmv} \mathrm{H}_{2} \mathrm{O}$, and the Type II (ice) PSC frost point temperature, respectively.

The PSC observations of CALIOP are consistent with the temperature history in this winter. Figure 2a shows an example of the PSC field on the $550 \mathrm{~K}$ potential temperature surface for 21 December 2009 with CALIOP observation points, when substantial PSC coverage was first observed by CALIOP at this altitude $(\sim 23 \mathrm{~km})$ in this Arctic winter. The global PSC field was created by assigning the value of the closest CALIOP PSC measurement on the same day to a given location. Note that the CALIOP PSC products are only produced for night time orbit segments due to higher background lighting conditions during daytime. On 21 December 2009 , the day/night transition occurs near $72^{\circ} \mathrm{N}$. Also note that the area north of $82^{\circ} \mathrm{N}$ is shadowed by grey color, because there is no CALIPSO orbital coverage there. Similarly, Fig. 2b shows an example of the PSC field at $550 \mathrm{~K}$ for 1 January 2010, when the maximum extent of PSCs was observed at this altitude. PSC fields were created this way for each day during the 2009/2010 Arctic winter.

\subsection{Selection of trajectories for the case studies}

As mentioned in Sect. 1, backward and forward trajectories from the positions of CALIOP PSC observations were calculated, in order to investigate the chemical effects of these PSCs by analyzing chemical model runs and trace gas observations along these trajectories. In order to exclude any chemical effect of earlier PSCs in the analyzed air masses, we concentrate on the time period of early winter (between 19 December 2009 and 3 January 2010). 

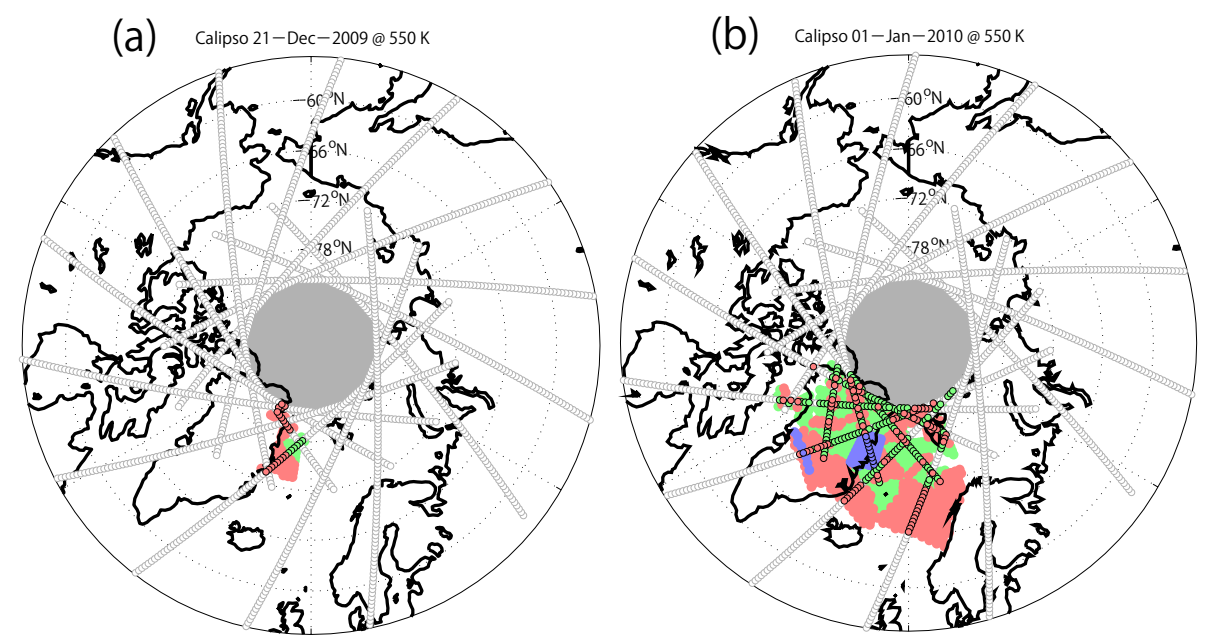

Figure 2. CALIOP PSC field for 21 December 2009 (a) and for 1 January 2010 (b) at the $550 \mathrm{~K}$ potential temperature surface. The green area represents STS PSCs, the red area mixed NAT and STS PSCs, and the blue area ice PSCs. Grey and black circles show CALIOP observation points for nighttime orbit segments. No measurements are available in the grey area around the pole $\left(>82^{\circ} \mathrm{N}\right)$ due to the orbital coverage of the CALIPSO satellite.

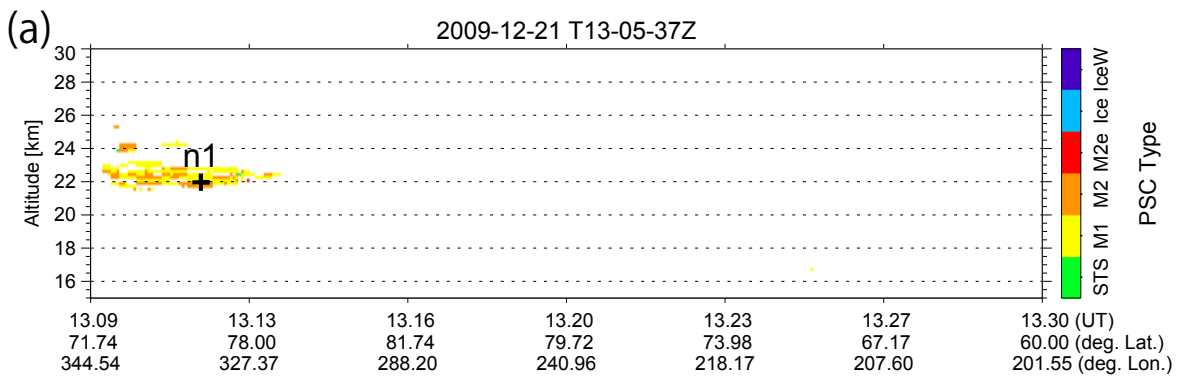

(b)

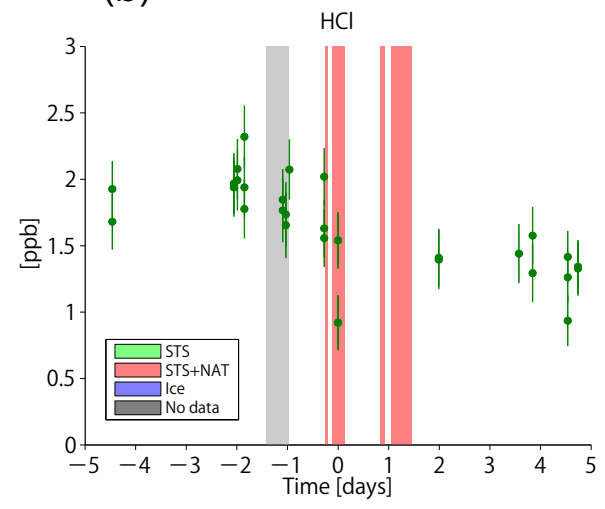

(c)

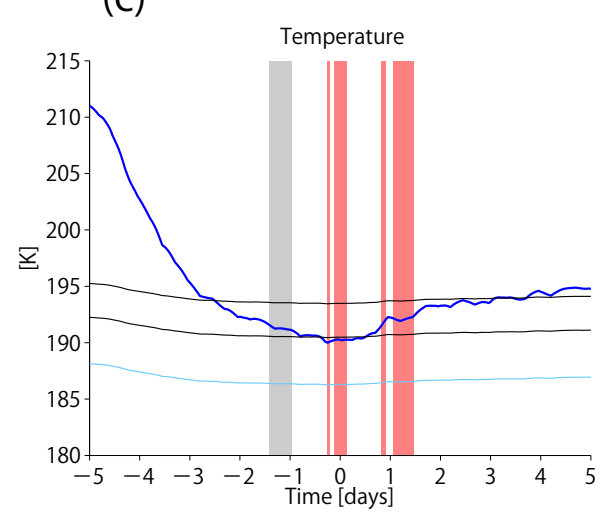

Figure 3. (a) Time-altitude plot of the PSC distribution on 21 December 2009 from 13.09 to 13.3 UTC (fractional hours). PSC classifications are color coded (STS, M1: Mix 1, M2: Mix 2, M2e: Mix 2 enhanced, Ice, IceW: Wave Ice; for details see Pitts et al., 2011). The labels on the horizontal axis show fractional time, latitude, and longitude. The cross with "n1" denotes the starting point of the forward/backward trajectories of panels (b) and (c) where Mix 1 PSC was present. (b) $\mathrm{HCl}$ measurements by MLS (green dots with error bars) along 5-day forward and 5-day backward trajectories starting at the cross in panel (a). The match radius between MLS measurements and the trajectory is $200 \mathrm{~km}$. The color-coded areas show PSC occurrence measured by CALIOP along the trajectories, with the same color code as in Fig. 2. Time is given relative to the trajectory starting time. (c) Temperature along the trajectories (blue line). The thin black lines show the threshold temperature for NAT formation $T_{\mathrm{NAT}}$ and $T_{\mathrm{NAT}}-3 \mathrm{~K}$. The thin blue line shows $T_{\mathrm{ice}}$. 


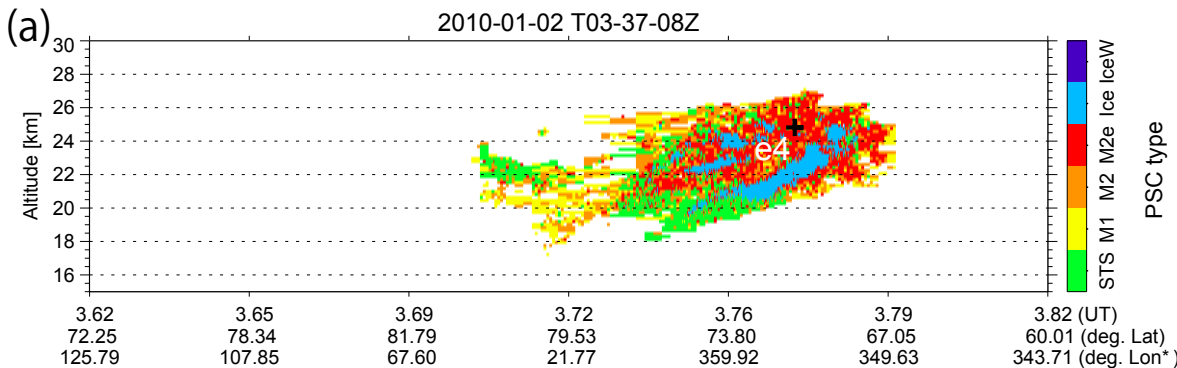

(b)

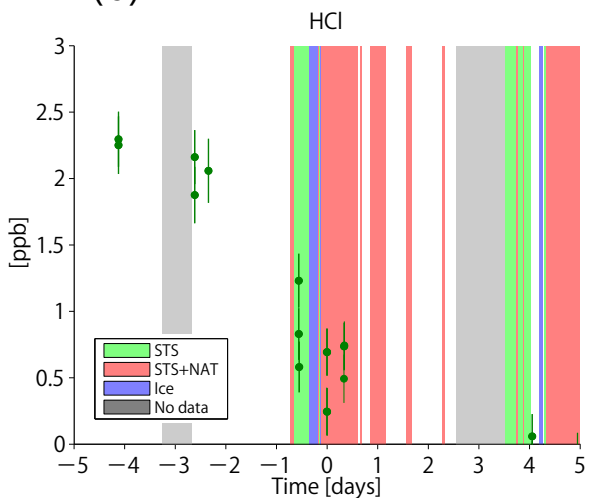

(c)

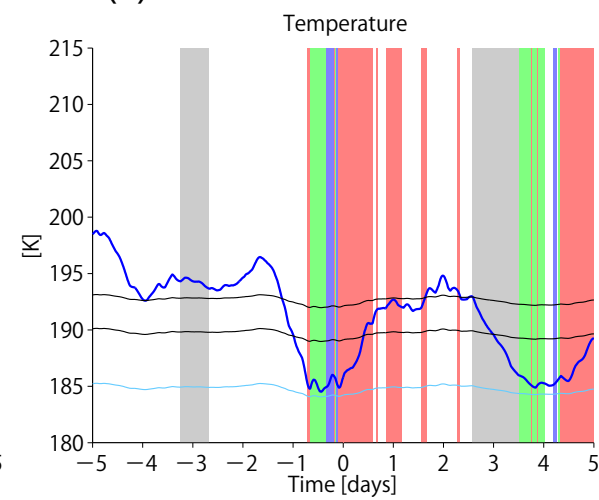

Figure 4. Same as Fig. 3 but for 2 January 2010 from 03.62 to 03.82 UTC. The cross with "e4" denotes the starting point of forward/backward trajectories where Mix 2 enhanced PSC was present.

As a first step, several cases of CALIOP observations of PSCs of a clearly defined composition class were selected. The selected cases encompass a range of different conditions with respect to temperature and PSC classification. Two examples are presented in Figs. 3 and 4. In each case, a location in the center of such a PSC was selected. It was marked by a cross and a label in Fig. 3a ("n1": Mix 1 PSC) and Fig. 4a ("e4": Mix 2 enhanced PSC). In order to show the temporal evolution of temperature and $\mathrm{HCl}$ in the analyzed air mass, 5day backward and 5-day forward trajectories, starting at the marked position, were calculated. The corresponding trajectory model is taken from the ATLAS chemistry and transport box model (Wohltmann et al., 2010). Model runs are driven by meteorological data from the ECMWF ERA-Interim reanalysis (Dee et al., 2011), with time resolution of $6 \mathrm{~h}$ and horizontal resolution of $2^{\circ} \times 2^{\circ}$. The vertical coordinate is potential temperature and vertical motion is driven by total diabatic heating rates from ERA-Interim.

Figures $3 b$ and $4 b$ show MLS measurements of $\mathrm{HCl}$ along the path of the trajectories as a function of time (green dots with error bars). All $\mathrm{HCl}$ measurements that were closer than $200 \mathrm{~km}$ to the position of the trajectory at a given point in time are plotted. PSC occurrence is color coded in the background. Green shaded areas correspond to STS clouds, red shaded areas to NAT/STS mixture clouds, and blue shaded areas to ice clouds. Grey areas correspond to sections of the trajectory north of $82^{\circ} \mathrm{N}$, where no measurements from CALIOP or MLS are available. Nevertheless, we can find some matched MLS points within the grey area in Fig. 3b. This is because MLS observations were selected within a match radius of $200 \mathrm{~km}$. Figures $3 \mathrm{~b}$ and $4 \mathrm{~b}$ show that $\mathrm{HCl}$ values were around $2 \mathrm{ppbv}$ on the backward trajectories and that either no PSCs were measured by CALIOP or no measurements from CALIOP were available on the backward trajectory. $\mathrm{HCl}$ started to decrease near $t=0$, a time at which PSCs were present according to our choice of the trajectory starting points. Figures $3 \mathrm{c}$ and $4 \mathrm{c}$ show the temperature along the trajectories, with the PSC occurrence as in Figs. $3 \mathrm{~b}$ and $4 \mathrm{~b}$. The thin black lines correspond to $T_{\mathrm{NAT}}$ and $T_{\mathrm{NAT}}-3 \mathrm{~K}$, the thin blue line corresponds to $T_{\text {ice }}$. The threshold temperature for the formation of NAT clouds $\left(T_{\mathrm{NAT}}\right)$ is based on the equations of Hanson and Mauersberger (1988). For the forward part of the trajectory, $\mathrm{HNO}_{3}$ and $\mathrm{H}_{2} \mathrm{O}$ from the box model runs (cf. Sect. 4) were used for the calculation of $T_{\mathrm{NAT}}$. For the backward part of the trajectory, $\mathrm{HNO}_{3}$ and $\mathrm{H}_{2} \mathrm{O}$ values were fixed at the starting values of the box model run. The threshold temperature for the formation of ice $\left(T_{\text {ice }}\right)$ was calculated in the same manner from the equations of Marti and Mauersberger (1993). In the cases shown in Figs. 3 and 4 , the temperature drops below $T_{\mathrm{NAT}}-3 \mathrm{~K}$ before the occurrence of the first PSCs shown in the plots. It can be seen that when temperature increased above $T_{\mathrm{NAT}}$, PSCs started to disappear along the path of the forward trajectory.

In order to analyze the temporal evolution of chemical species after the encounter of PSCs, ATLAS box model runs, which will be explained in the following section in detail, 
Table 1. List of the selected cases for the trajectory runs. The first column shows the ID number of the case used in the following analysis, the second column the starting date, and the third column the starting time of the trajectory. The remaining columns show the location of the starting position $(t=0)$ of the forward and backward trajectories.

\begin{tabular}{lrrrrrrr}
\hline Case ID & Date & Time $(\mathrm{UT})$ & Latitude (N) & Longitude (E) & Altitude $(\mathrm{km})$ & PT $(\mathrm{K})$ & Pressure $(\mathrm{hPa})$ \\
\hline No. 01 & $2009 / 12 / 19$ & $16: 37: 56$ & 79.85 & 263.71 & 22.36 & 520.9 & 31.60 \\
No. 02 & $2009 / 12 / 21$ & $08: 09: 30$ & 75.50 & 50.54 & 22.97 & 559.2 & 27.91 \\
No. 03 & $2009 / 12 / 23$ & $07: 58: 21$ & 78.90 & 39.92 & 22.07 & 526.0 & 31.60 \\
No. 04 & $2009 / 12 / 23$ & $07: 58: 45$ & 79.85 & 33.50 & 22.05 & 522.9 & 31.60 \\
No. 05 & $2009 / 12 / 30$ & $17: 53: 38$ & 66.13 & 279.29 & 22.97 & 546.4 & 27.44 \\
No. 06 & $2009 / 12 / 31$ & $08: 58: 26$ & 57.56 & 264.93 & 21.00 & 511.8 & 40.68 \\
No. 07 & $2009 / 12 / 31$ & $12: 10: 25$ & 76.70 & 241.31 & 22.15 & 531.7 & 31.60 \\
No. 08 & $2009 / 12 / 31$ & $16: 59: 14$ & 70.28 & 288.19 & 24.05 & 565.3 & 22.61 \\
No.09 & $2009 / 12 / 31$ & $18: 35: 15$ & 60.44 & 273.13 & 24.95 & 612.4 & 19.84 \\
No. 10 & $2010 / 01 / 01$ & $09: 39: 12$ & 66.12 & 260.59 & 22.97 & 551.0 & 27.60 \\
No. 11 & $2010 / 01 / 01$ & $17: 41: 15$ & 66.12 & 282.38 & 24.05 & 570.7 & 23.24 \\
\hline
\end{tabular}

will be performed on several trajectory cases. It is desirable to start these model runs from initial concentrations that have not been influenced by any earlier PSC occurrence in the air mass of interest. However, if these model runs started at the locations selected in the center of a PSC (as those marked in Figs. 3a and 4a), then a part of the backward trajectory would lie within the selected PSC. Consequently, some chlorine activation might occur already before the beginning of the forward trajectory. In order to avoid this effect, the forward trajectories for the runs of the ATLAS box model are started before the encounter of the selected PSC. For this, a new starting point (corresponding to a new starting time $t=0$ ) of the trajectory calculations was selected on the original backward trajectory, such that it fulfills the following conditions:

1. There is no PSC in the CALIOP data near the backward trajectory before the new starting time.

2. The temperature at and before the new starting time does not drop below $T_{\mathrm{NAT}}-3 \mathrm{~K}$. The assumption behind this is that a supersaturation of a factor of 10 ( $3 \mathrm{~K}$ supercooling) is needed for the formation of NAT clouds and that STS clouds only take up measurable quantities of $\mathrm{HNO}_{3}$ below $T_{\mathrm{NAT}}-3 \mathrm{~K}$ (Dye et al., 1992; Pitts et al., 2007).

3. The matched MLS $\mathrm{HCl}$ values at and before the new starting time were above $\sim 2 \mathrm{ppbv}$, which proves that the air mass has not been processed by PSCs before the new $t=0$.

In such a way, we selected $\sim 30$ trajectory cases in early winter between 19 December 2009 and 3 January 2010 for several PSC classes. Then we selected 11 trajectories for case studies, which cover several different PSC composition classification and different temperature histories. The new trajectory starting points are summarized in Table 1 . Starting from these points, new 5-day forward and 5-day backward trajectories were calculated. ATLAS box model was run on these 5-day forward trajectories, which passed through the center part of the selected PSCs.

\section{ATLAS model}

\subsection{Model description}

The box model runs, simulating the temporal evolution of chemical species along the trajectories described in Sect. 3.2, use the chemistry box model of the ATLAS model (Wohltmann et al., 2010). Updates to the chemistry model and PSC model are described in Wohltmann et al. (2013). The model includes a gas-phase stratospheric chemistry module and heterogeneous chemistry on PSCs. It comprises 47 active species and more than 180 reactions. Absorption cross sections and rate coefficients are taken from recent JPL recommendations (Sander et al., 2011). The chemical model runs are driven by meteorological data from the ECMWF ERAInterim reanalysis (Dee et al., 2011).

In regard to the treatment of conditions where both NAT and STS PSCs are allowed to form in parallel, the model has changed compared to Wohltmann et al. (2013) to allow for more realistic behavior. In Wohltmann et al. (2013), only liquid clouds could form between $T_{\mathrm{NAT}}$ and the temperature corresponding to the assumed supersaturation for $\mathrm{HNO}_{3}$ over NAT. At temperatures below that of the assumed supersaturation, NAT clouds would form first, usually consuming all available $\mathrm{HNO}_{3}$ and impeding the formation of ternary liquid clouds (by chance, the temperature where binary liquid aerosols begin to take up $\mathrm{HNO}_{3}$ in measurable quantities is about the same as the temperature where NAT clouds begin to form in the model). Since NAT/STS mixtures are commonly observed (e.g., Pitts et al., 2011), we implemented a simple algorithm that allows for mixed clouds: if the given supersaturation of $\mathrm{HNO}_{3}$ over NAT is exceeded, only a predefined fraction of the amount of $\mathrm{HNO}_{3}$ that has to be removed from the gas phase to reach the supersaturation again is allowed to 
go into NAT clouds. The remaining fraction is available for the formation of STS clouds. The fraction is set to 0.2 for our model runs.

In the ATLAS model run, the NAT particle number density is set to $0.1 \mathrm{~cm}^{-3}$, the ice particle number density is set to $0.01 \mathrm{~cm}^{-3}$, and the STS droplet number density is set to $10 \mathrm{~cm}^{-3}$. A supersaturation of $\mathrm{HNO}_{3}$ over NAT of 10 (corresponding to about $3 \mathrm{~K}$ supercooling) is required for NAT particle formation. A detailed discussion of the rationale behind these choices can be found in Wohltmann et al. (2013). For ice particle formation, a supersaturation of 0.35 is assumed based on MLS satellite measurements of $\mathrm{H}_{2} \mathrm{O}$ and ECMWF temperatures. Reaction rates for NAT particles are based on scheme 1 in Carslaw et al. (1997) and reaction rates for liquid particles are based on Hanson and Ravishankara (1994).

\subsection{Chemical initialization}

The model chemical initialization is performed in three steps. First, all of the species are initialized from the mixing ratio fields of an existing global model run of ATLAS for the winter 2009/2010 (the reference run in Wohltmann et al., 2013). For this, a short back trajectory is calculated from the starting position of each trajectory back to the time of the last model output of the global model run preceding the start date of the trajectory. The chemical model is then run forward on this short trajectory with the initialization taken from the nearest air parcel of the global model output.

In the second step, mixing ratio values for $\mathrm{HCl}, \mathrm{O}_{3}$, and $\mathrm{H}_{2} \mathrm{O}$ are replaced by measurements from MLS. MLS gasphase $\mathrm{HNO}_{3}$ observations are not used, in order to avoid problems when some of the total available $\mathrm{HNO}_{3}$ is in the condensed phase (the model needs total $\mathrm{HNO}_{3}$ and MLS measures gas-phase $\mathrm{HNO}_{3}$ ). The MLS values for $\mathrm{HCl}, \mathrm{O}_{3}$, and $\mathrm{H}_{2} \mathrm{O}$ are obtained by calculating a 5-day back trajectory from the starting point of each trajectory and calculating an average over all MLS measurements close to the trajectory (with a match radius of $200 \mathrm{~km}$ ). In order to keep $\mathrm{Cl}_{y}$ (the sum of all inorganic species containing chlorine) constant at the value specified by the global ATLAS runs, the difference between the MLS $\mathrm{HCl}$ value and the $\mathrm{HCl}$ value of the global model run is added to (or subtracted from, depending on the sign) the mixing ratio of $\mathrm{ClONO}_{2}$. Note that no chlorine activation has yet taken place at the time when the model is initialized and this correction does not produce negative $\mathrm{ClONO}_{2}$ values for any of the trajectories.

In some cases (trajectories no. 05, no. 08, and no. 10), modeled $\mathrm{ClONO}_{2}$ is fully depleted before $\mathrm{HCl}$ reaches the level indicated by the MLS measurements. In these cases, a third step is applied to ensure that $\mathrm{HCl}$ and $\mathrm{ClONO}_{2}$ are adjusted such that the amount of $\mathrm{HCl}$ loss in the model matches the loss of $\mathrm{HCl}$ in the MLS data. In all of these cases, there is a significant difference between the observed $\mathrm{HCl}$ mixing ratios before and after the PSC occurrence. The magnitude of this observed drop in $\mathrm{HCl}$ is used as the initialization for
$\mathrm{ClONO}_{2}$, such that $\mathrm{ClONO}_{2}$ is nearly depleted at the end of the box model run. In order to keep $\mathrm{Cl}_{y}$ constant again, the difference between the new $\mathrm{ClONO}_{2}$ value (taken from the decrease in observed $\mathrm{HCl}$ ) and the old $\mathrm{ClONO}_{2}$ value (after the first correction in the second step caused by MLS $\mathrm{HCl}$ ) is added to (or subtracted from) $\mathrm{ClO}_{x}=\mathrm{ClO}+2 \mathrm{Cl}_{2} \mathrm{O}_{2}$ in a way that preserves the partitioning between $\mathrm{ClO}$ and $\mathrm{Cl}_{2} \mathrm{O}_{2}$.

\section{Results}

\subsection{Dependence of PSC classification on temperature history}

In this section, we show the temporal change in PSC classification along eight selected trajectories with different temperature histories.

Figure 5a-b show cases in which the air mass cooled gradually over a period of days to below $T_{\mathrm{NAT}}-3 \mathrm{~K}$. NAT/STS mixture PSCs started to appear when the air mass temperature decreased below approximately $T_{\mathrm{NAT}}-4 \mathrm{~K}$ in both cases shown. No ice PSCs and only a negligible amount of STS PSCs were observed during the course of the trajectory. When temperatures warmed above $T_{\mathrm{NAT}}$ in trajectory case no. 01, the mixed PSCs mostly disappeared. Since there was no region within the polar vortex with temperatures below the frost point before these PSC events, the NAT/STS mixture PSC observed here was assumed to be formed without any prior exposure to ice PSCs.

Figure $6 \mathrm{a}-\mathrm{c}$ show cases in which the air mass temperature decreased rather rapidly due to adiabatic cooling by orographic lift as it passed over Greenland. In these cases, STS formed first as the temperature decreased below approximately $T_{\mathrm{NAT}}-4 \mathrm{~K}$, followed by a transition to NAT/STS mixture PSCs as the temperature warmed to near $T_{\mathrm{NAT}}$. When the temperature rose above $T_{\mathrm{NAT}}$, the PSCs disappeared.

Figure $7 \mathrm{a}-\mathrm{c}$ show cases where the air mass temperature decreased rapidly to $T_{\text {ice }}$ due to adiabatic cooling by orographic lift as it passed over Greenland. In these cases, STS formed first as the temperature decreased below approximately $T_{\mathrm{NAT}}-4 \mathrm{~K}$, followed by the formation of ice as the temperature decreased to $T_{\text {ice }}$. As the temperature warms above $T_{\text {ice, }}$, the ice PSC is transformed into a NAT/STS mixture PSC, as suggested by an old theory of NAT PSC formation (Koop et al., 1995). The CALIOP ice PSC observations coincide quite well with the trajectory segments when air mass temperatures cooled near $T_{\text {ice. }}$. This proves the accuracy of ECMWF ERA-Interim reanalysis temperature data to some extent even in a mesoscale scenario such as mountaininduced adiabatic cooling event. 


\section{Gradual cooling cases}
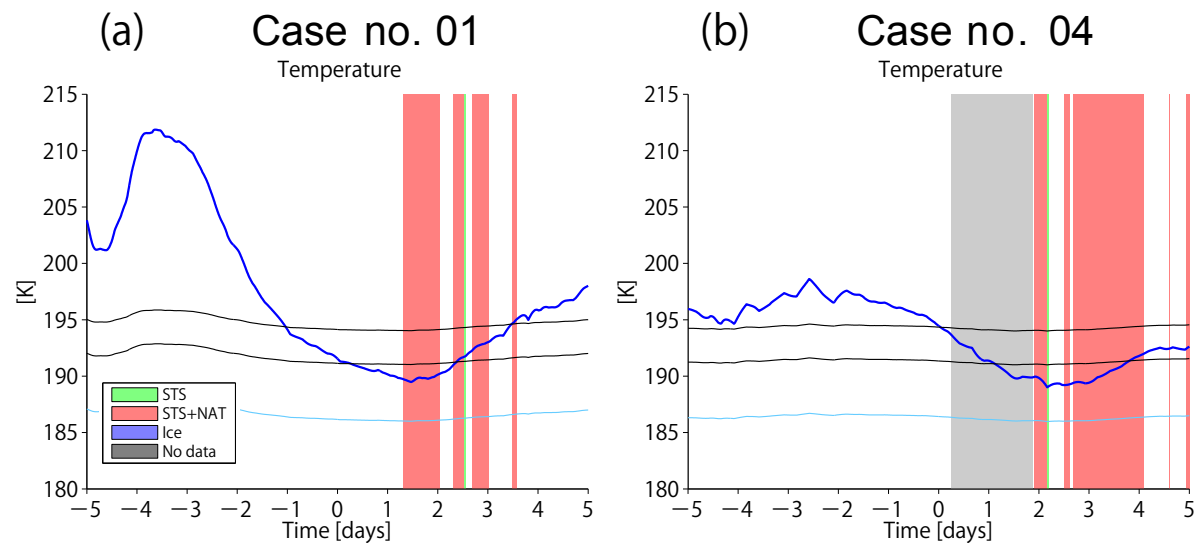

Figure 5. Temperature along the trajectories for case no. 01 (a) started at 16:37:56 UT on 19 December 2009 at an altitude of $22.36 \mathrm{~km}$, and no. 04 (b) started at 07:58:21 UT on 23 December 2009 at an altitude of $22.05 \mathrm{~km}$, as listed in Table 1 . The color-coded areas show PSC occurrence measured by CALIOP along the trajectories, with the color code shown in lower left of panel (a). Shaded grey area represents that PSC types were unknown due to the CALIPSO orbital limitation $\left(>82^{\circ} \mathrm{N}\right)$. The thin black lines show the threshold temperature for NAT formation $T_{\mathrm{NAT}}$ and $T_{\mathrm{NAT}}-3 \mathrm{~K}$. The thin blue line shows $T_{\text {ice }}$.

NAT formation by rapid adiabatic cooling cases
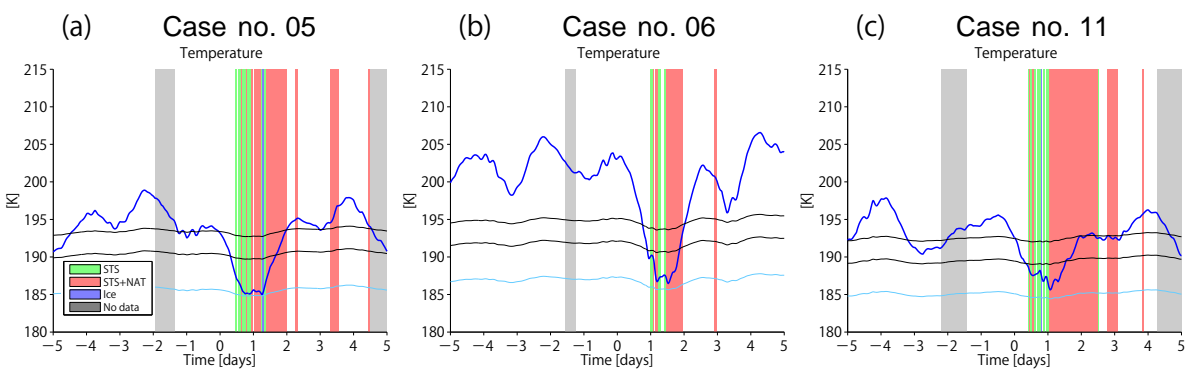

Figure 6. Same as Fig. 5 but for trajectory case no. 05 (a), starting at 17:53:38 UT on 30 December 2009 at an altitude of $22.97 \mathrm{~km}$; no. 06 (b), starting at 08:58:26 UT on 31 December 2009 at an altitude of $21.00 \mathrm{~km}$; and no. 11 (c), starting at 17:41:15 UT on 1 January 2010 at an altitude of $24.05 \mathrm{~km}$, respectively.

Ice formation by rapid adiabatic cooling cases
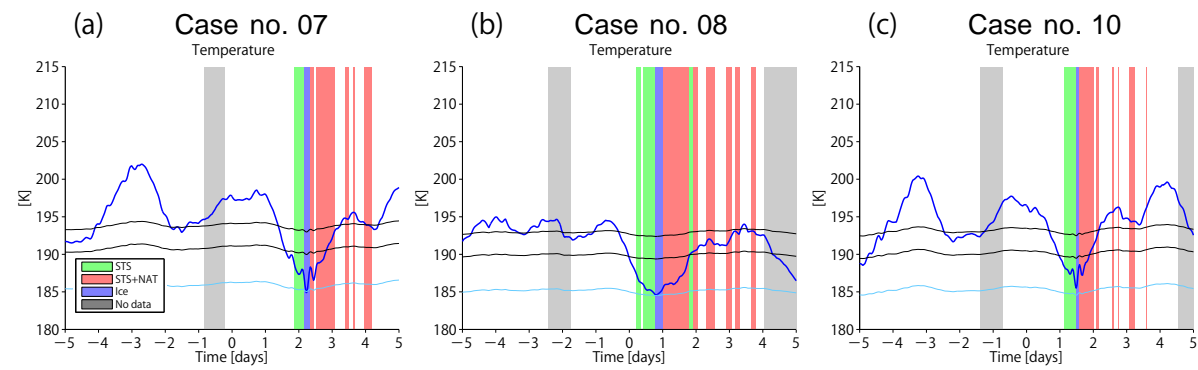

Figure 7. Same as Fig. 5 but for trajectory case no. 07 (a), starting at 12:10:25 UT on 31 December 2009 at an altitude of $22.15 \mathrm{~km}$; no. 08 (b), starting at 16:59:14 UT on 31 December 2009 at an altitude of $24.05 \mathrm{~km}$; and no. 10 (c), starting at 09:39:12 UT on 1 January 2010 at an altitude of $22.97 \mathrm{~km}$, respectively. 

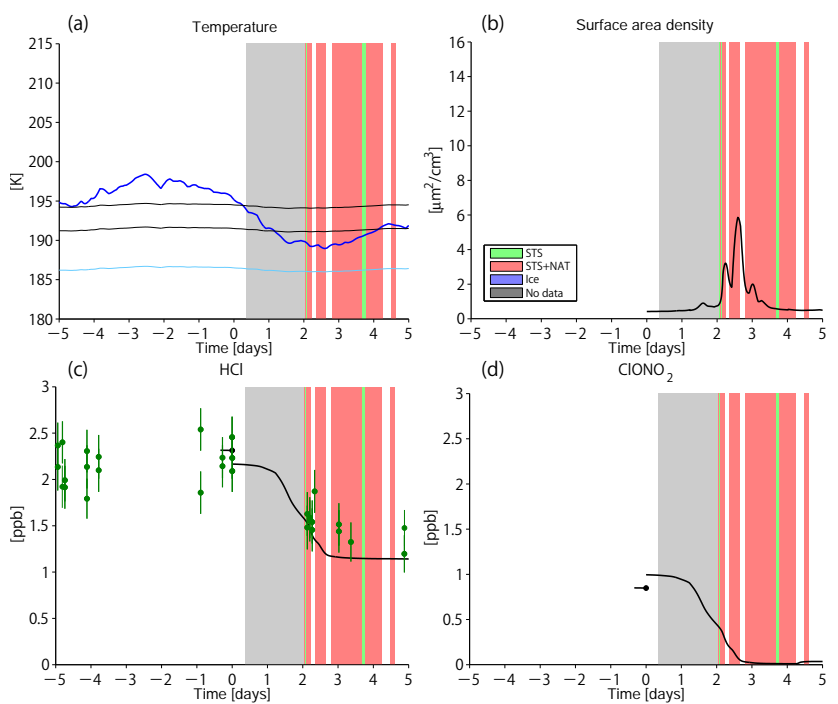

(d)

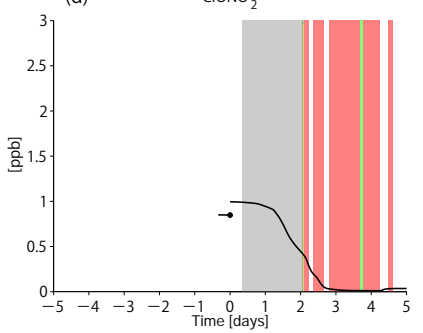

(e) $\quad \mathrm{ClO}_{x}\left(\mathrm{ClO}_{2}+2 \mathrm{Cl}_{2} \mathrm{O}_{2}\right)+2 \mathrm{Cl}_{2}$
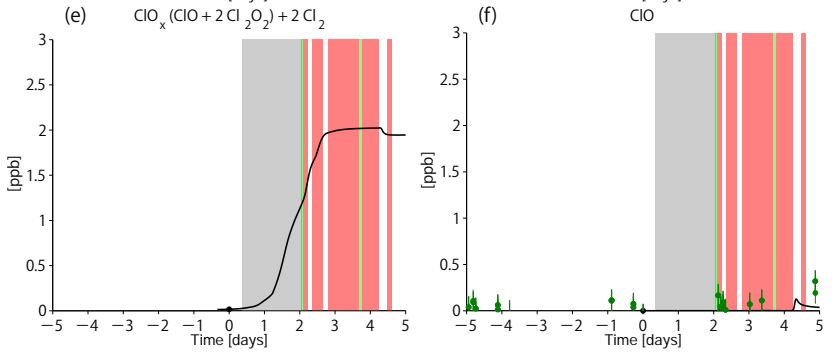

Figure 8. Results of the ATLAS chemistry model along the trajectories and comparison with measurements by MLS for the trajectory case no. 03 starting at 07:58:21 UT on 23 December 2009 at an altitude of $22.07 \mathrm{~km}$. (a) Temperature (as in Figs. 5-7), (b) PSC surface area density, (c) $\mathrm{HCl}$ mixing ratio, (d) $\mathrm{ClONO}_{2}$ mixing ratio, (e) $\mathrm{ClO}_{x}\left(\mathrm{ClO}+2 \times \mathrm{Cl}_{2} \mathrm{O}_{2}\right)+2 \times \mathrm{Cl}_{2}$ mixing ratio, (f) $\mathrm{ClO}$ mixing ratio. Matched MLS measurements of $\mathrm{HCl}$ and $\mathrm{ClO}$ are shown in panels (c) and (f) (green dots with error bars). Black line in panels (b)-(f) show ATLAS model results. The color-coded areas show PSC occurrence measured by CALIOP along the trajectories, with the color code shown in lower left of panel (b).

\subsection{Comparison of MLS measurements with the ATLAS model}

In this section, we show the temporal changes of several parameters modeled by ATLAS and compare these with Aura/MLS measurements.

Figure $8 \mathrm{a}-\mathrm{f}$ show the trajectory case no. 03 that started at 07:58:21 UT on 23 December 2009. It is not known if PSCs existed between 8 and $49 \mathrm{~h}$ after the starting time of the forward trajectory because the trajectory went into the polar region above $82^{\circ} \mathrm{N}$ latitude where there are no CALIOP measurements. At hour 49, the air mass encountered STS and then NAT/STS mixture PSCs as the temperature cooled below approximately $T_{\mathrm{NAT}}-4 \mathrm{~K}$ as shown in Fig. 8a. The surface area density of the PSCs calculated by ATLAS is shown in Fig. 8b. ATLAS indicated a small increase in surface area density between days 1 and 2 when the temperature
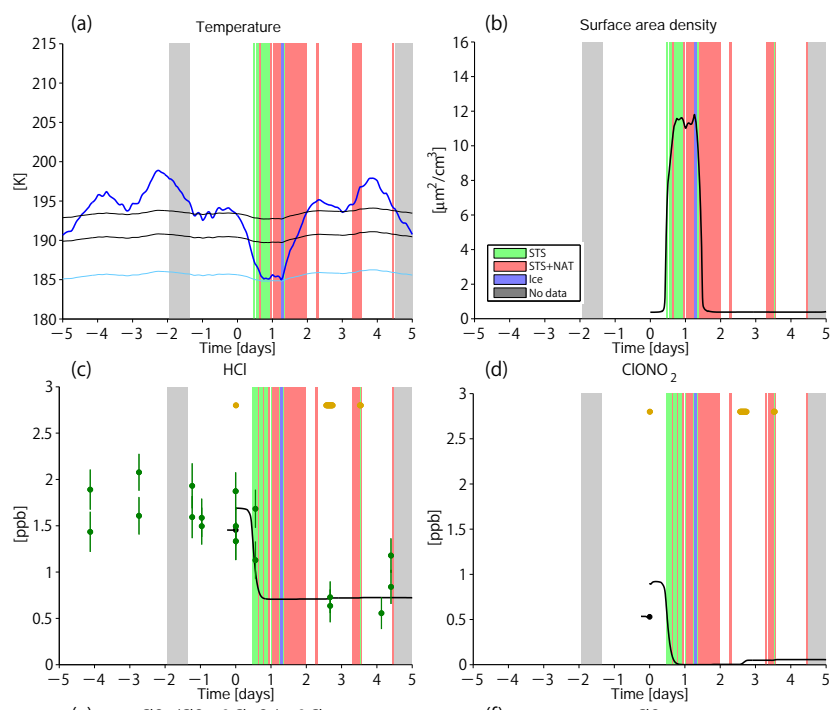

(e) $\quad \mathrm{ClO}_{x}\left(\mathrm{ClO}+2 \mathrm{Cl}_{2} \mathrm{O}_{2}\right)+2 \mathrm{Cl}_{2}$
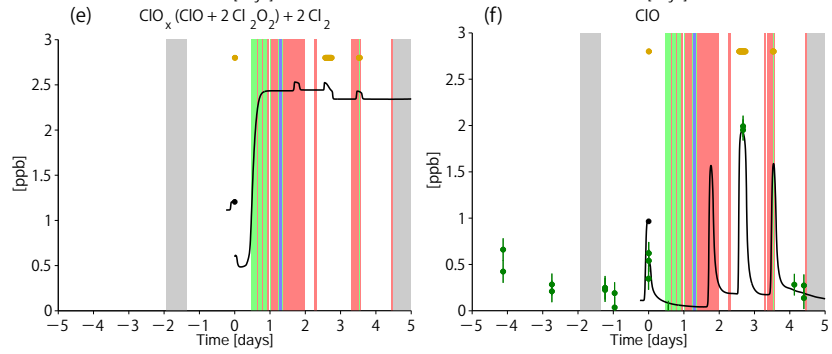

Figure 9. Same as Fig. 8 but for trajectory case no. 05, starting at 17:53:38 UT on 30 December 2009 at an altitude of $22.97 \mathrm{~km}$. The orange dots in panels (c)-(f) indicate the period of solar illumination when the solar zenith angle is smaller than $90^{\circ}$.

decreased approximately $4 \mathrm{~K}$ below $T_{\mathrm{NAT}}$, where CALIOP was not able to measure in that period due to the sampling limitation stated above. Figure 8c shows the calculated and measured amount of $\mathrm{HCl}$ by ATLAS and by Aura/MLS, respectively. MLS observations were matched to the trajectory with a match radius of $200 \mathrm{~km}$, as was explained in Sect. 3.2. When the temperature decreased to about $T_{\mathrm{NAT}}-3 \mathrm{~K}$, the calculated $\mathrm{HCl}$ started to decrease in the model run. Similarly, $\mathrm{ClONO}_{2}$ started to decrease and was fully depleted between days 2 and 3 as shown in Fig. 8d. After this point, $\mathrm{HCl}$ could not decrease anymore because the reaction partner $\left(\mathrm{ClONO}_{2}\right)$ was already fully depleted. The measured and calculated $\mathrm{HCl}$ values agree quite well within the error bars of MLS measurements as expected. The depleted chlorine was converted into $\mathrm{Cl}_{2}$ or $\mathrm{ClO}_{x}$ as shown in Fig. 8e. Because little sunlight was present along the trajectory, only a small amount of $\mathrm{ClO}_{x}$ exists in the form of $\mathrm{ClO}$ as shown in Fig. $8 \mathrm{f}$ after day 4.

Figure $9 \mathrm{a}-\mathrm{f}$ show the trajectory case no. 05 that started at 17:53:38 UT on 30 December 2009. The trajectory encountered a region of CALIOP STS measurements after $10 \mathrm{~h}$ as the temperature decreased below approximately $T_{\mathrm{NAT}}-5 \mathrm{~K}$. Between days 1 and 5, NAT/STS mixture PSCs were ob- 

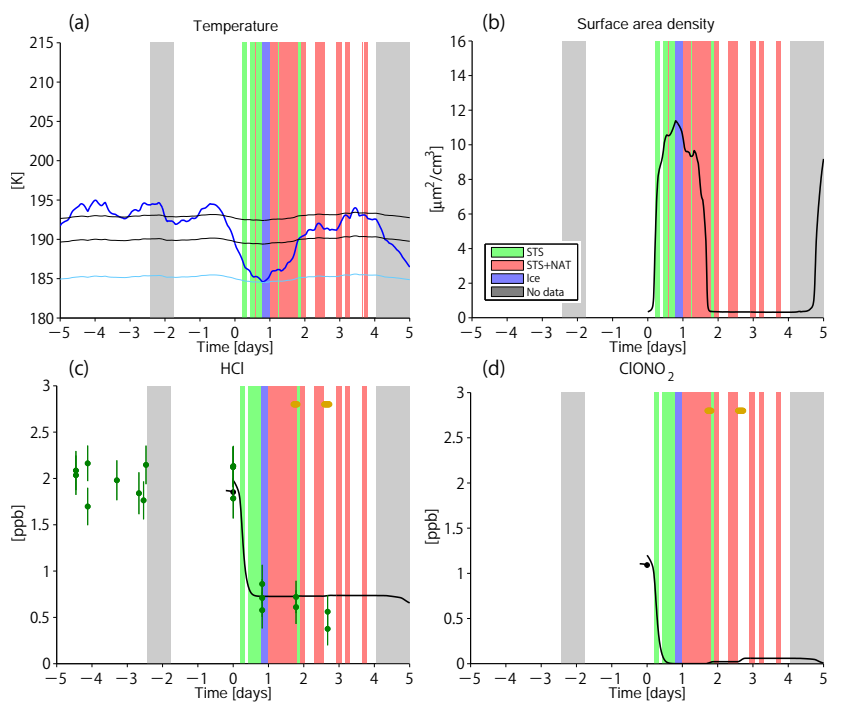

(d)

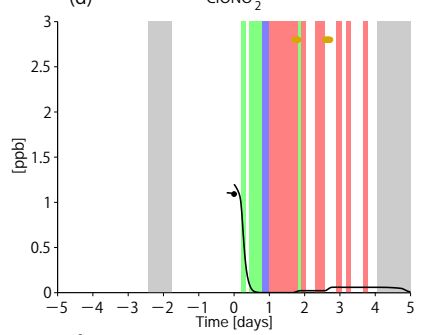

(e) $\quad \mathrm{ClO}_{x}\left(\mathrm{ClO}_{2}+2 \mathrm{Cl}_{2} \mathrm{O}_{2}\right)+2 \mathrm{Cl}_{2}$
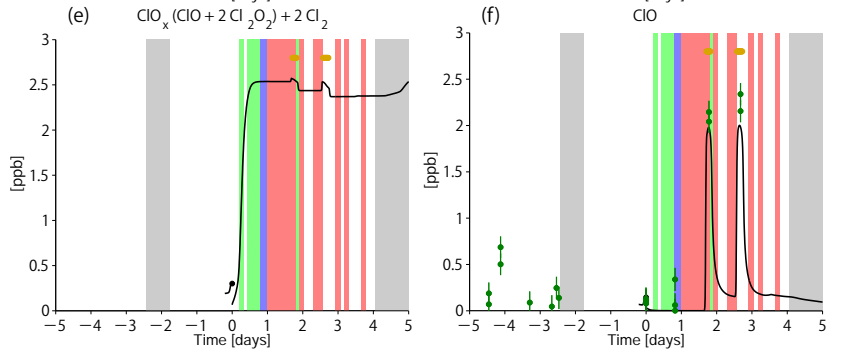

Figure 10. Same as Fig. 8 but for trajectory case no. 08, starting at 16:59:14 UT on 31 December 2009 at an altitude of $24.05 \mathrm{~km}$.

served along the trajectory, as well as a very short period of ice PSCs between days 1 and 2 when the temperature cooled to $T_{\text {ice. }}$. Calculated PSC surface area density increased rapidly when the air mass temperature decreased below around $T_{\mathrm{NAT}}-3 \mathrm{~K}$ between days 0 and 2 as shown in Fig. 9b. However, both $\mathrm{HCl}$ and $\mathrm{ClONO}_{2}$ stopped decreasing just a few hours after the air mass encountered the STS PSCs, because the $\mathrm{ClONO}_{2}$ was fully depleted within this time as shown in Fig. 9c and d. The measured and calculated $\mathrm{HCl}$ values agree quite well. The depleted reservoir chlorine was first converted into $\mathrm{Cl}_{2}$, then after exposure to sunlight (indicated by orange dots on the upper part of Fig. $9 \mathrm{c}-\mathrm{f}$ ), $\mathrm{Cl}_{2}$ was photolyzed to $\mathrm{Cl}$ which forms $\mathrm{ClO}_{x}$ (Fig. 9e and f). The measured and calculated $\mathrm{ClO}$ values also agree quite well.

Figure 10a-f show the trajectory case no. 08 that started at 16:59:14 UT on 31 December 2009. After $3 \mathrm{~h}$, the air mass encountered STS PSCs as the temperature decreased below approximately $T_{\mathrm{NAT}}-5 \mathrm{~K}$. As the temperature further decreased to reach $T_{\text {ice }}$ after $20 \mathrm{~h}$, ice PSCs were observed by CALIOP as shown in Fig. 10a. When the temperature increased above $T_{\text {ice }}$ after $23 \mathrm{~h}$, NAT/STS mixture PSCs were observed. This case is quite similar to the previous case. Calculated PSC surface area density rapidly increased when the air mass cooled to around $T_{\text {ice }}$ between days 0 and 2 as shown in Fig. 10b. However, both $\mathrm{HCl}$ and $\mathrm{ClONO}_{2}$ stopped de-
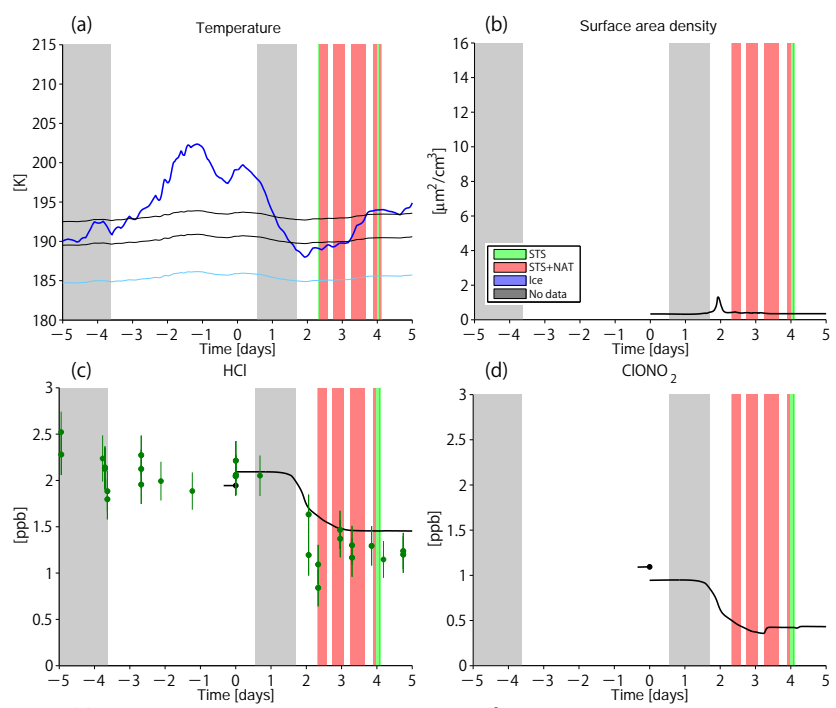

(e) $\quad \mathrm{ClO}_{x}\left(\mathrm{ClO}_{2}+\mathrm{Cl}_{2} \mathrm{O}_{2}\right)+2 \mathrm{Cl}_{2}$
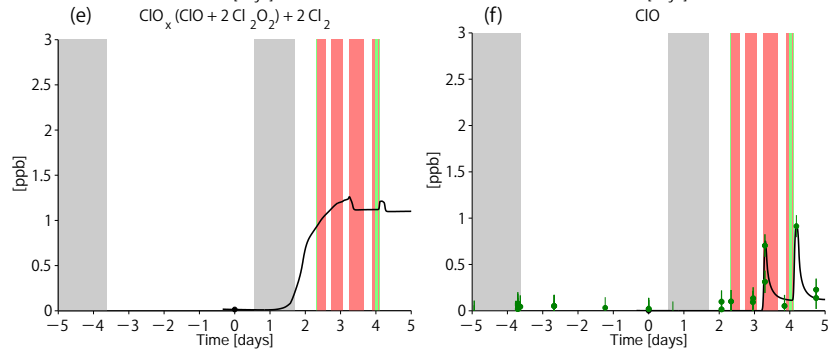

Figure 11. Same as Fig. 8 but for trajectory case no. 02, starting at 08:09:30 UT on 21 December 2009 at an altitude of $24.05 \mathrm{~km}$.

creasing just a few hours after the air mass encountered STS PSCs, because $\mathrm{ClONO}_{2}$ was fully depleted within this time as shown in Fig. 10c and d. Also in this case, the measured and calculated $\mathrm{HCl}$ values agree quite well. The depleted reservoir chlorine was first converted into $\mathrm{Cl}_{2}$, then with exposure to sunlight (indicated by orange dots on the upper part of Fig. $10 \mathrm{c}-\mathrm{f}), \mathrm{Cl}_{2}$ was photolyzed to $\mathrm{Cl}$ which was then converted into $\mathrm{ClO}$ as shown in Fig. $10 \mathrm{f}$.

\subsection{Temperature sensitivity study for ATLAS model runs}

Figure $11 \mathrm{a}-\mathrm{f}$ show the trajectory case no. 02 that started at 08:09:30 UT on 21 December 2009. After $55 \mathrm{~h}$, the air mass encountered STS PSCs as the temperature decreased below $T_{\mathrm{NAT}}-4 \mathrm{~K}$ for a while. Shortly afterwards, a mixed type PSC was observed by CALIOP. When temperature increased to around $T_{\mathrm{NAT}}$ at day 4 , STS PSC was observed again before the air mass exited the PSC area. In this case, the time period when the temperature was below $T_{\mathrm{NAT}}-4 \mathrm{~K}$ was relatively short as shown in Fig. 11a. As a result, the higher values of PSC surface area calculated by ATLAS were limited to a short time period at around day 2 as shown in Fig. 11 b. As a result, the decrease of both $\mathrm{HCl}$ and $\mathrm{ClONO}_{2}$ modeled by ATLAS was small and $\mathrm{ClONO}_{2}$ was not totally depleted 

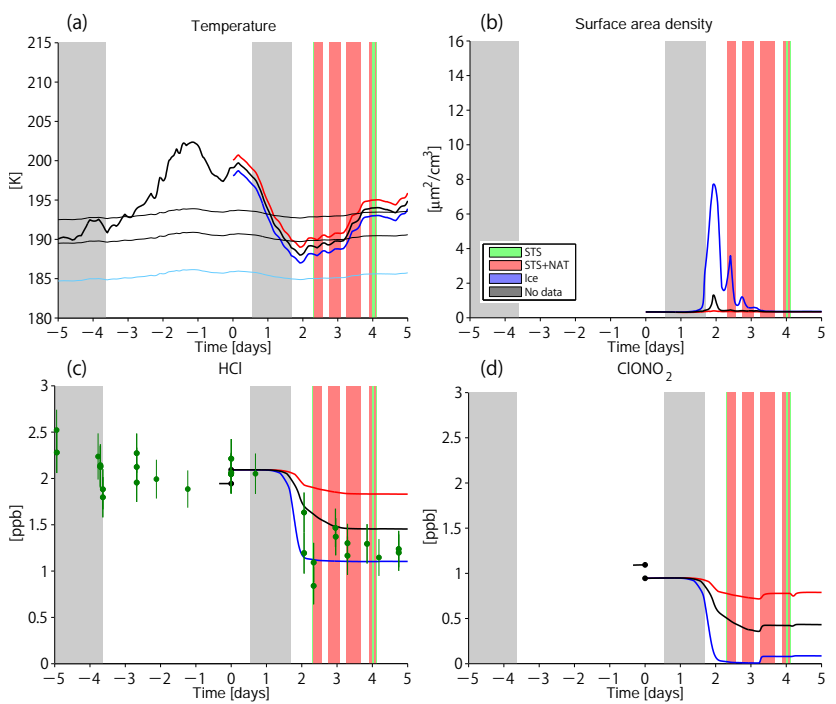

(d)

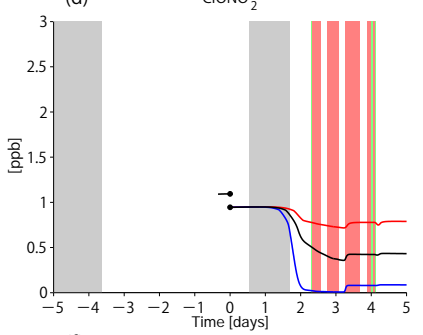

(e) $\quad \mathrm{ClO}_{x}\left(\mathrm{ClO}+2 \mathrm{Cl}_{2} \mathrm{O}_{2}\right)+2 \mathrm{Cl}$
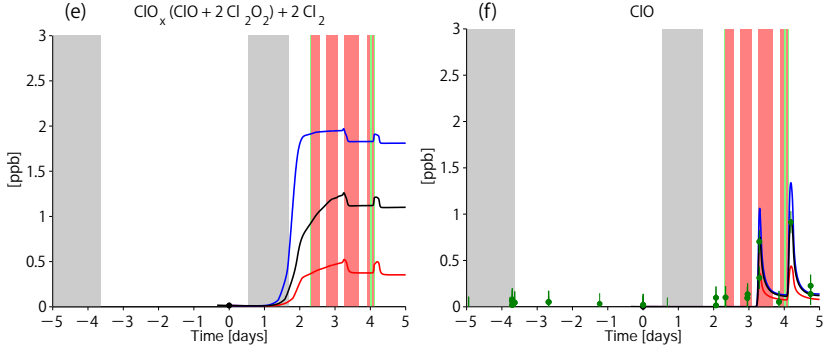

Figure 12. Temperature sensitivity runs for trajectory case no. 02 . The black line shows the standard run, the red line a sensitivity run with temperature increased by $1 \mathrm{~K}$, and the blue line a sensitivity run with temperature decreased by $1 \mathrm{~K}$. MLS measurements and PSC types are the same as in Fig. 11.

even after passage through the PSCs. In addition, the ATLAS model underestimates the loss of $\mathrm{HCl}$ compared with observations as shown in Fig. 11c.

In order to study the sensitivity of the ATLAS model runs to the ECMWF ERA-Interim reanalysis temperatures, we made additional ATLAS model runs by introducing a $\pm 1 \mathrm{~K}$ temperature bias. Figure 12a-f show the same trajectory as Fig. 11a-f with red and blue lines added to show the sensitivity runs with the temperature changed by $\pm 1 \mathrm{~K}$, respectively. The reference run (black line) used no temperature biases. As shown in Fig. 12b, a temperature change of only $1 \mathrm{~K}$ greatly affects the PSC surface area density. As a result, the modeled depletion of $\mathrm{HCl}$ and $\mathrm{ClONO}_{2}$ are also significantly affected as shown in Fig. 12c and d. In fact, the minus $1 \mathrm{~K}$ model run result agrees fairly well with the MLS $\mathrm{HCl}$ observations as shown in Fig. 12c. This result suggests the previous studies (e.g., Carslaw et al., 1994) which showed that very accurate temperature data are required to correctly model the heterogeneous reactions on PSCs at temperatures near $T_{\mathrm{NAT}}-4 \mathrm{~K}$.

Figure 13a-f show another example; trajectory case no. 09 which started at 18:35:15 UT on 31 December 2009. After $18 \mathrm{~h}$, the air mass encountered NAT/STS mixture PSCs as
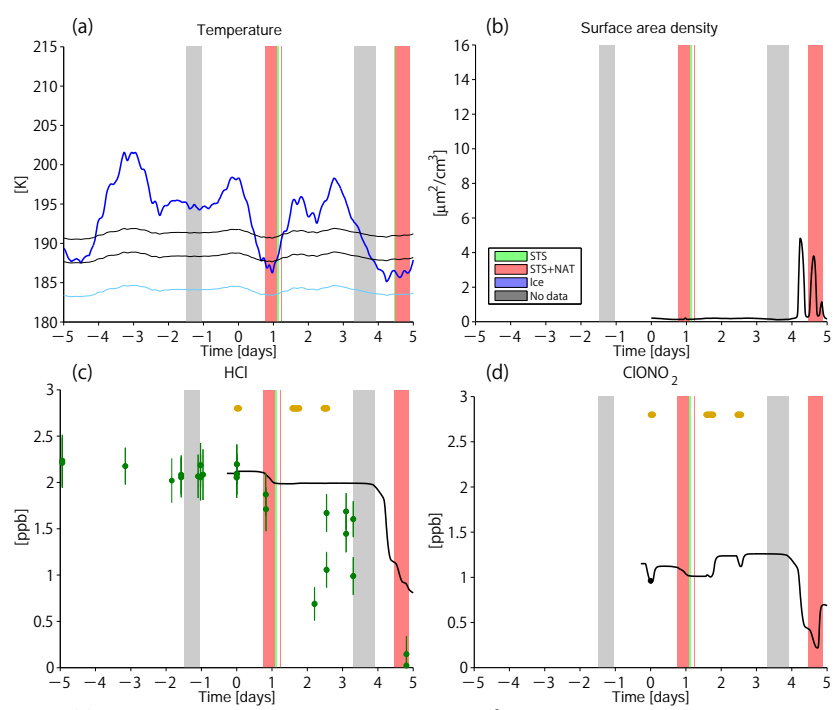

(e) $\quad \mathrm{ClO}_{x}\left(\mathrm{ClO}+2 \mathrm{Cl}_{2} \mathrm{O}_{2}\right)+2 \mathrm{Cl}_{2}$
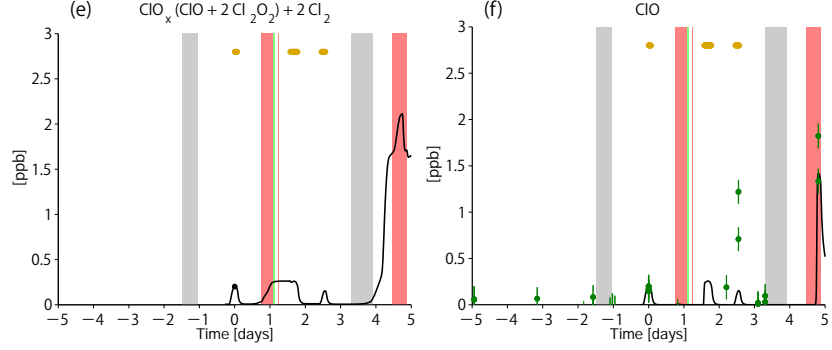

Figure 13. Same as Fig. 8 but for trajectory case no. 09, starting at 18:35:15 UT on 31 December 2009 at an altitude of $24.95 \mathrm{~km}$.

the temperature decreased below approximately $T_{\mathrm{NAT}}-3 \mathrm{~K}$. In this case, the time period when the temperature was below $T_{\mathrm{NAT}}-3 \mathrm{~K}$ was very short (less than $10 \mathrm{~h}$ ), as shown in Fig. 13a. Accordingly, the modeled increase of PSC surface area density was very small as shown in Fig. 13b. Consequently, the model did not produce substantial $\mathrm{HCl}$ or $\mathrm{ClONO}_{2}$ depletion around day 1, as shown in Fig. 13c and d. However, MLS $\mathrm{HCl}$ measurements do indicate some depletion between days 2 and 4, as shown in Fig. 13c.

Figure 14a-f show the results of the temperature sensitivity study for case no. 09. As shown by Fig. 14b, perturbing the ECMWF temperature field by minus $1 \mathrm{~K}$ greatly increases the likelihood of PSCs around day 1. Consequently, the modeled $\mathrm{HCl}$ depletion for the minus $1 \mathrm{~K}$ case agrees with the MLS measurements quite well as shown in Fig. 14c. This result again illustrates the importance of accurate temperature data especially when the temperature is around $T_{\mathrm{NAT}}-4 \mathrm{~K}$, which is the approximate threshold temperature of NAT/STS mixture and STS PSC formation. 

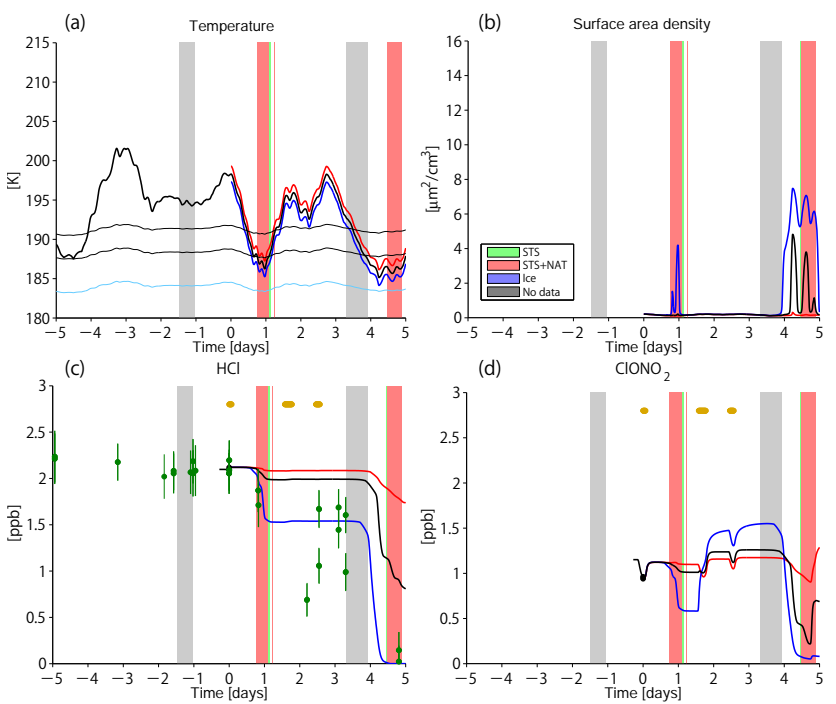

(d)

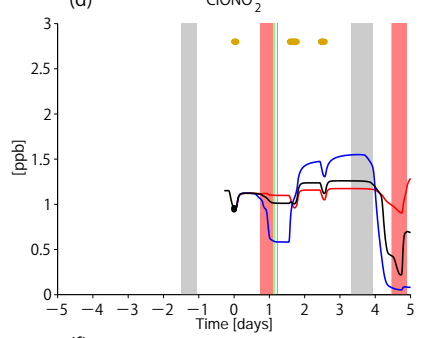

(e) $\quad \mathrm{ClO}_{x}\left(\mathrm{ClO}_{2} \mathrm{Cl}_{2} \mathrm{O}_{2}\right)+2 \mathrm{Cl}$
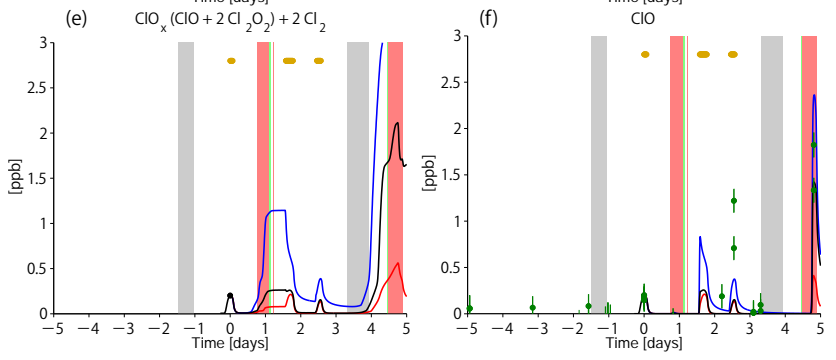

Figure 14. Temperature sensitivity runs for trajectory case no. 09. Line colors here are the same as those in Fig. 12.

\section{Discussion}

In Sect. 5.1, we showed three typical temperature histories for PSC formation, i.e., gradual temperature decrease, rapid temperature decrease, and temperature decrease below $T_{\text {ice }}$. Figure $5 \mathrm{a}-\mathrm{b}$ show the formation of NAT/STS mixture PSCs for the case of gradual temperature decrease in air masses that have never experienced temperatures below $T_{\text {ice. }}$. These cases clearly show the existence of an ice-free nucleation mechanism of NAT, as was previously suggested by Drdla et al. (2003), Larsen et al. (2004), Pagan et al. (2004), Voigt et al. (2005), Pitts et al. (2011), and Hoyle et al. (2013). The homogeneous nucleation of NAT in $\mathrm{H}_{2} \mathrm{O}-\mathrm{H}_{2} \mathrm{SO}_{4}-\mathrm{HNO}_{3}$ solutions is kinetically strongly hampered and thus cannot be expected (Koop et al., 1997). One of the possible mechanisms for NAT formation is heterogeneous nucleation on solid particles such as meteoritic dust, as was postulated by Iraci et al. (1995), although Biermann et al. (1996) suggested that heterogeneous nucleation rates on micrometeorites are too low to enable freezing of NAT PSCs. Our results suggest the possibility of heterogeneous nucleation of NAT on solid particles as is already pointed out by Hoyle et al. (2013).

When the air mass temperature cooled rapidly due to adiabatic cooling by passage over mountain ranges, STS PSCs first formed as the temperature decreased below approxi- mately $T_{\mathrm{NAT}}-4 \mathrm{~K}$ as shown in Fig. $6 \mathrm{a}-\mathrm{c}$. As the air mass temperature began to increase, a transition to NAT/STS mixture PSCs was observed without the existence of ice, especially for case no. 06. Such a case was previously reported in PSC observations by backscatter sondes in the Arctic by Larsen et al. (1997). This result also indicates the possibility of ice-free formation of NAT.

Figure $7 \mathrm{a}-\mathrm{c}$ show the cases when the air mass temperature decreased rapidly below $T_{\text {ice }}$ due to adiabatic cooling over mountain ranges. As the air mass temperature began to increase, a transition to NAT/STS mixture PSCs was observed in all these cases. NAT/STS mixture PSCs usually disappear when the temperature warms above $T_{\mathrm{NAT}}$. These cases are consistent with the ice-assisted nucleation mechanism of NAT suggested by Carslaw et al. (1995).

In Sect. 5.2, comparisons of MLS $\mathrm{HCl}, \mathrm{ClO}$, and $\mathrm{O}_{3}$ measurements with ATLAS model simulation results were shown for the trajectory cases no. 03, no. 05, and no. 08. Figure $8 \mathrm{a}-\mathrm{f}$ shows the gradual temperature decrease for case no. 03, Fig. 9a-f shows the rapid temperature decrease for case no. 05, and Fig. 10a-f shows the temperature decrease below $T_{\text {ice }}$ for case no. 08 . In all three cases, measured and modeled $\mathrm{HCl}$ and $\mathrm{ClO}$ agree fairly well. The chlorine activation usually occurred very rapidly within a few hours. The amount of $\mathrm{HCl}$ loss was shown to be limited by the available $\mathrm{ClONO}_{2}$ amount. After all the $\mathrm{ClONO}_{2}$ has been converted into $\mathrm{ClO}_{x}, \mathrm{HCl}$ cannot be further depleted as previously shown in a model study by Müller et al. (1994).

In Sect. 5.3, similar comparison results were shown for case no. 02 and no. 09, when the air mass temperature was below approximately $T_{\mathrm{NAT}}-4 \mathrm{~K}$ for only a short time period. In these trajectory cases, the depletion of $\mathrm{HCl}$ and activation of $\mathrm{ClO}$ was underestimated by the model in comparison to the MLS measurements. In these cases, $\mathrm{ClONO}_{2}$ was not totally depleted after passage through the PSCs. In cases where only a small amount of chlorine is activated, the amount of chlorine activation on PSCs is very dependent on air mass temperature. In fact, changing the ECMWF ERAInterim temperature field used as input to the ATLAS model by $\pm 1 \mathrm{~K}$ has a large impact on the resulting magnitude of chlorine activation as shown in Figs. 12a-f and 14a-f. The large temperature sensitivity around $T_{\mathrm{NAT}}-4 \mathrm{~K}$ can be attributed to the fact that both PSC surface area density and heterogeneous reaction probability (gamma value) increase quite rapidly around this temperature. Therefore, we conclude that quite accurate temperature knowledge is needed to correctly model the chlorine activation amount at around $T_{\mathrm{NAT}}-4 \mathrm{~K}$. 


\section{Conclusions}

We performed trajectory analyses to study the evolution of PSC composition and chlorine activation from the reservoir species of $\mathrm{HCl}$ and $\mathrm{ClONO}_{2}$. We investigated which PSCs form according to measurements of CALIOP as a function of the temperature history along the trajectories. We studied 11 individual trajectories in the early Arctic winter 2009/2010. In cases of a gradual temperature decrease below approximately $T_{\mathrm{NAT}}-4 \mathrm{~K}, \mathrm{NAT} / \mathrm{STS}$ mixture PSCs appeared first. In these cases, ice PSCs were not observed by CALIOP before the formation of the mixed clouds, nor were temperatures below $T_{\text {ice }}$ observed. This provides strong additional observational support for the conclusions by Drdla et al. (2003), Larsen et al. (2004), Pagan et al. (2004), Voigt et al. (2005), Pitts et al. (2011), and Hoyle et al. (2013) that NAT clouds can form without the prior formation of ice clouds. Since laboratory experiments suggest that homogenous freezing of NAT is unlikely, a possible mechanism of ice-free formation of NAT could be heterogeneous nucleation on solid particulates such as meteoritic dust (Voigt et al., 2005; Hoyle et al., 2013), although Biermann et al. (1996) suggested that heterogeneous reaction rates on micrometeorites are too low. When the air mass temperature dropped rapidly due to adiabatic cooling, STS PSCs formed first when the temperature decreased below approximately $T_{\mathrm{NAT}}-4 \mathrm{~K}$. If the temperature further decreased below $T_{\text {ice }}$, ice PSCs were formed. Then, when the air mass temperature started to increase above $T_{\text {ice }}$, NAT/STS mixture PSCs were formed, as suggested by the formation pathway of NAT clouds from ice clouds (e.g., Carslaw et al., 1995).

We further analyzed the chlorine activation process based on MLS observations of $\mathrm{HCl}$ and $\mathrm{ClO}$ and the ATLAS Chemistry and Transport Model runs. Several sensitivity runs with different temperature histories were conducted. We find that our cases fall in one of two categories.

1. In most cases, chlorine activation occurred sufficiently rapidly, such that the degree of chlorine activation by the first PSC encounter for the respective air mass was limited by the initially available $\mathrm{ClONO}_{2}$, i.e., $\mathrm{ClONO}_{2}$ concentrations fell to very low values. For these cases, ATLAS model results, i.e., the modeled mixing ratios of $\mathrm{HCl}$ and $\mathrm{ClO}$ before and after the chlorine activation by the PSCs, generally agreed well with the MLS observations. The good agreement is expected, since for these cases the degree of chlorine activation only depends on available $\mathrm{ClONO}_{2}$ and is largely insensitive to the rate of the heterogeneous reactions and therefore to the exact PSC temperature.

2. In a few cases, temperatures during the first PSC encounter remained higher (around $T_{\mathrm{NAT}}-4 \mathrm{~K}$ ) and the chlorine activation is slower, such that the rates of the heterogeneous reactions integrated over the time of exposure to PSCs limit the degree of chlorine activation, rather than the available amount of $\mathrm{ClONO}_{2}$. In these cases, substantial amounts of $\mathrm{ClONO}_{2}$ can survive the initial PSC encounter and the model is not always able to reproduce the degree of chlorine activation. In particular, the sensitivity of chlorine activation to temperature is extremely large in these situations, suggesting that a temperature uncertainty of $\pm 1 \mathrm{~K}$ is sufficient to explain the discrepancy between modeled and measured $\mathrm{HCl}$ amount. However, based on the data from the winter $2009 / 2010$, these situations are fairly rare. $T_{\mathrm{NAT}}-4 \mathrm{~K}$ is an approximate threshold temperature for rapid chlorine activation on PSCs.

Author contributions. H. Nakajima and M. Takeda designed the method of this study. I. Wohltmann developed and ran the ATLAS box model, ran trajectory calculations, and developed the PSC interpolation algorithm. T. Wegner, M. C. Pitts, and L. R. Poole developed and analyzed PSC observations from CALIPSO/CALIOP data. M. L. Santee developed and analyzed minor species from Aura/MLS data. H. Nakajima, I. Wohltmann, R. Lehmann, and M. Rex discussed on the analysis results. H. Nakajima prepared the manuscript with contributions from all co-authors.

Acknowledgements. We acknowledge European Centre for Medium-Range Weather Forecasts (ECMWF) for providing us with the ERA-Interim reanalysis data. We also acknowledge Atmospheric Chemistry and Dynamics Laboratory (Code 614) of Goddard Space Flight Center, National Aeronautics and Space Administration (NASA) for providing the MERRA annual minimum temperature to produce Fig. 1. One of the authors (HN) appreciates the warm hospitality given by all the members of Alfred Wegener Institute for Polar and Marine Research at Potsdam, Germany when he was staying there for half a year as a sabbatical visit. Work at the Jet Propulsion Laboratory, California Institute of Technology, was done under contract with NASA.

Edited by: J.-U. Grooß

\section{References}

Biermann, U. M., Presper, T., Koop, T., Mößinger, J., Crutzen, P. J., and Peter, T.: The unsuitability of meteoritic and other nuclei for polar stratospheric cloud freezing, Geophys. Res. Lett., 23, 1693-1696, 1996.

Carslaw, K. S., Luo, B. P., Clegg, S. L., Peter, T., Brimblecombe, P., and Crutzen, P. J.: Stratospheric aerosol growth and $\mathrm{HNO}_{3}$ gas phase depletion from coupled $\mathrm{HNO}_{3}$ and water uptake by liquid particles, Geophys. Res. Lett., 21, 2479-2482, 1994.

Carslaw, K. S., Peter, T., and Müller, R.: Uncertainties in reactive uptake coefficients for solid stratospheric particles -2 . Effect on ozone depletion, Geophys. Res. Lett., 24, 1747-1750, 1997.

Crutzen, P. J. and Arnold, F.: Nitric acid cloud formation in the cold Antarctic stratosphere: a major cause for the springtime "ozone hole", Nature, 324, 651-655, 1986. 
Dee, D. P., Uppala, S. M., Simmons, A. J., Berrisford, P., Poli, P., Kobayashi, S., Andrae, U., Balmaseda, M. A., Balsamo, G., Bauer, P., Bechtold, P., Beljaars, A. C. M., van de Berg, L., Bidlot, J., Bormann, N., Delsol, C., Dragani, R., Fuentes, M., Geer, A. J., Haimberger, L., Healy, S. B., Hersbach, H., Hólm, E. V., Isaksen, L., Kållberg, P., Köhler, M., Matricardi, M., McNally, A. P., Monge-Sanz, B. M., Morcrette, J.-J., Park, B.K., Peubey, C., de Rosnay, P., Tavolato, C., Thépaut, J.-N., and Vitart, F.: The ERA-Interim reanalysis: configuration and performance of the data assimilation system, Q. J. Roy. Meteor. Soc., 137, 553-597, 2011.

Dörnbrack, A., Pitts, M. C., Poole, L. R., Orsolini, Y. J., Nishii, K., and Nakamura, H.: The 2009-2010 Arctic stratospheric winter general evolution, mountain waves and predictability of an operational weather forecast model, Atmos. Chem. Phys., 12, 36593675, doi:10.5194/acp-12-3659-2012, 2012.

Drdla, K. and Schoeberl, M. R.: Microphysical modeling of the 1999-2000 Arctic winter, 2, Chlorine activation and ozone depletion. J. Geophys. Res., 108, 8319, doi:10.1029/2001JD001159, 2003.

Drdla, K., Schoeberl, M. R., and Browell, E. V.: Microphysical modeling of the 1999-2000 Arctic winter, 1, Polarstratospheric clouds, denitrification, and dehydration. J. Geophys. Res., 108, 8312, doi:10.1029/2001JD000782, 2003.

Dye, J. E., Baumgardner, D., Gandrud, B. W., Kawa, S. R., Kelly, K. K., Loewenstein, M., Ferry, G. V., Chan, K. R., and Gary, B. L.: Particle size distribution in Arctic polar stratospheric clouds, growth and freezing of sulfuric acid droplets, and implications for cloud formation, J. Geophys. Res., 30, 8015-8034, 1992.

Farman, J. C., Gardiner, B. G., and Shanklin, J. D.: Large losses of total ozone in Antarctica reveal seasonal $\mathrm{ClO}_{x} / \mathrm{NO}_{x}$ interaction, Nature, 315, 207-210, 1985.

Hanson, D. and Mauersberger, K.: Laboratory studies of the nitric acid trihydrate: implications for the south polar stratosphere, Geophys. Res. Lett., 15, 855-858, 1988.

Hanson, D. R. and Ravishankara, A. R.: Reactive uptake of $\mathrm{ClONO}_{2}$ onto sulfuric acid due to reaction with $\mathrm{HCl}$ and $\mathrm{H}_{2} \mathrm{O}$, J. Phys. Chem., 98, 5728-5735, 1994.

Hoyle, C. R., Engel, I., Luo, B. P., Pitts, M. C., Poole, L. R., Grooß, J.-U., and Peter, T.: Heterogeneous formation of polar stratospheric clouds - Part 1: Nucleation of nitric acid trihydrate (NAT), Atmos. Chem. Phys., 13, 9577-9595, doi:10.5194/acp13-9577-2013, 2013.

Iraci, L. T., Middlebrook, A. M., and Tolbert, M. A.: Laboratory studies of the formation of polar stratospheric clouds: nitric acid condensation on thin sulphuric acid films, J. Geophys. Res., 100, 20969-20977, 1995.

Koop, T., Biermann, U. M., Raber, W., Luo, B. P., Crutzen, P. J., and Peter, T.: Do stratospheric aerosol droplets freeze above the ice frost point?, Geophys. Res. Lett., 22, 917-920, 1995.

Koop, T., Carslaw, K. S., and Peter, T.: Thermodynamic stability and phase transitions of PSC particles, Geophys. Res. Lett., 24, 2199-2202, 1997.

Lambert, A., Santee, M. L., Wu, D. L., and Chae, J. H.: A-train CALIOP and MLS observations of early winter Antarctic polar stratospheric clouds and nitric acid in 2008, Atmos. Chem. Phys., 12, 2899-2931, doi:10.5194/acp-12-2899-2012, 2012.
Larsen, N., Knudsen, B. M., Rosen, J. M., Kjome, N. T., Neuber, R., and Kyrö, E.: Temperature histories in liquid and solid polar stratospheric cloud formation, J. Geophys. Res., 102, 2350523517, 1997.

Larsen, N., Knudsen, B. M., Svendsen, S. H., Deshler, T., Rosen, J. M., Kivi, R., Weisser, C., Schreiner, J., Mauerberger, K., Cairo, F., Ovarlez, J., Oelhaf, H., and Spang, R.: Formation of solid particles in synoptic-scale Arctic PSCs in early winter 2002/2003, Atmos. Chem. Phys., 4, 2001-2013, doi:10.5194/acp-4-2001-2004, 2004.

Livesey, N., Van Snyder, W., Read, W., and Wagner, P.: Retrieval algorithms for the EOS Microwave Limb Sounder (MLS), IEEE T. Geosci. Remote, 44, 1144-1155, doi:10.1109/TGRS.2006.872327, 2006.

Livesey, N. J., Read, W. G., Froidevaux, L., Lambert, A., Manney, G. L., Pumphrey, H. C., Santee, M. L., Schwartz, M. J., Wang, S., Cofeld, R. E., Cuddy, D. T., Fuller, R. A., Jarnot, R. F., Jiang, J. H., Knosp, B. W., Stek, P. C., Wagner, P. A., and Wu, D. L.: Version 3.3 and 3.4 Level 2 data quality and description document, D-33509, Jet Propulsion Laboratory, available at: http://mls.jpl.nasa.gov/ (last access: 5 August 2015), 2013.

Marti, J. and Mauersberger, K.: A survey and new measurements of ice vapour pressure at temperatures between 170 and $250 \mathrm{~K}$, Geophys. Res. Lett., 20, 363-366, 1993.

Molina, L. T. and Molina, M. J.: Production of $\mathrm{Cl}_{2} \mathrm{O}_{2}$ from the selfreaction of the ClO radical, J. Phys. Chem., 91, 433-436, 1987.

Müller, R., Peter, Th., Crutzen, P. J., Oelhaf, H., Adrian, G. P., v. Clarmann, Th., Wegner, A., Schmidt, U., and Lary, D.: Chlorine chemistry and the potential for ozone depletion in the arctic stratosphere in the winter of 1991/92, Geophys. Res. Lett., 21, 1427-1430, 1994.

Pagan, K. L., Tabazadeh, A., Drdla, K., Hervig, M. E., Eckermann, S. D., Browell, E. V., Legg, M. J., and Foschi, P. G.: Observational evidence against mountain-wave generation of ice nuclei as a prerequisite for the formation of three solid nitric acid polar stratospheric clouds observed in the Arctic in early December 1999, J. Geophys. Res., 109, D04312, doi:10.1029/2003JD003846, 2004.

Peter, T. and Grooß, J.-U.: Polar stratospheric clouds and sulfate aerosol particles: microphysics, denitrification and heterogeneous chemistry, in: Stratospheric Ozone Depletion and Climate Change, edited by: Müller, R., Royal Society of Chemistry, 2012.

Pitts, M. C., Thomason, L. W., Poole, L. R., and Winker, D. M.: Characterization of Polar Stratospheric Clouds with spaceborne lidar: CALIPSO and the 2006 Antarctic season, Atmos. Chem. Phys., 7, 5207-5228, doi:10.5194/acp-7-5207-2007, 2007.

Pitts, M. C., Poole, L. R., and Thomason, L. W.: CALIPSO polar stratospheric cloud observations: second-generation detection algorithm and composition discrimination, Atmos. Chem. Phys., 9, 7577-7589, doi:10.5194/acp-9-7577-2009, 2009.

Pitts, M. C., Poole, L. R., Dörnbrack, A., and Thomason, L. W.: The 2009-2010 Arctic polar stratospheric cloud season: a CALIPSO perspective, Atmos. Chem. Phys., 11, 2161-2177, doi:10.5194/acp-11-2161-2011, 2011.

Portmann, R. W., Solomon, S., Garcia, R. R., Thomason, L. W., Poole, L. R., and McCormick, M. P.: Role of aerosol variations in anthropogenic ozone depletion in the polar regions, J. Geophys. Res., 101, 22991-23006, 1996. 
Sander, S. P., Abbatt, J., Barker, J. R., Burkholder, J. B., Friedl, R. R., Golden, D. M., Huie, R. E., Kolb, C. E., Kurylo, M. J., Moortgat, G. K., Orkin, V. L., and Wine, P. H.: Chemical kinetics and photochemical data for use in atmospheric studies, Evaluation Number 17, JPL Publication 10-06, Jet Propulsion Laboratory, California Institute of Technology, Pasadena, available at: http://jpldataeval.jpl.nasa.gov (last access: 5 August 2015), 2011.

Solomon, S., Garcia, R. R., Rowland, F. S., and Wuebbles, D. J.: On the depletion of Antarctic ozone, Nature, 321, 755-758, 1986.

Solomon, S., Kinnison, D., Bandoro, J., and Garcia, R.: Simulation of polar ozone depletion: An update, J. Geophys. Res., 120, 7958-7974, doi:10.1002/2015JD023365, 2015.

Voigt, C., Schreiner, J., Kohlmann, A., Zink, P., Mauersberger, K., Larsen, N., Deshler, T., Kröger, C., Rosen, J., Adriani, A., Cairo, F., Di Donfrancesco, G., Viterbini, M., Ovarlez, J., Ovarlez, H., David, C., and Dörnbrack, A.: Nitric acid trihydrate (NAT) in polar stratospheric clouds, Science, 290, 1756-1758, 2000.

Voigt, C., Schlager, H., Luo, B. P., Dörnbrack, A., Roiger, A., Stock, P., Curtius, J., Vössing, H., Borrmann, S., Davies, S., Konopka, P., Schiller, C., Shur, G., and Peter, T.: Nitric Acid Trihydrate (NAT) formation at low NAT supersaturation in Polar Stratospheric Clouds (PSCs), Atmos. Chem. Phys., 5, 13711380, doi:10.5194/acp-5-1371-2005, 2005.

Waters, J. W., Froidevaux, L., Harwood, R. S., Jarnot, R. F., Pickett, H. M., Read, W. G., Siegel, P. H., Coeld, R. E., Filipiak, M. J., Flower, D. A., Holden, J. R., Lau, G. K., Livesey, N. J., Manney, G. L., Pumphrey, H. C., Santee, M. L., Wu, D. L., Cuddy, D. T., Lay, R. R., Loo, M. S., Perun, V. S., Schwartz, M. J., Stek, P. C., Thurstans, R. P., Chandra, K. M., Chavez, M. C., Chen, G.-S., Boyles, M. A., Chudasama, B. V., Dodge, R., Fuller, R. A., Girard, M. A., Jiang, J. H., Jiang, Y., Knosp, B. W., LaBelle, R. C., Lam, J. C., Lee, K. A., Miller, D., Oswald, J. E., Patel, N. C., Pukala, D. M., Quintero, O., Scaff, D. M., Snyder, W. V., Tope, M. C., Wagner, P. A., and Walch, M. J.: The Earth Observing System Microwave Limb Sounder (EOS MLS) on the Aura satellite, IEEE T. Geosci. Remote, 44, 1075-1092, 2006.
Winker, D. M., McGill, M., and Hunt, W. H.: Initial performance assessment of CALIOP, Geophys. Res. Lett., 34, L19803, doi:10.1029/2007GL030135, 2007.

Winker, D. M., Vaughan, M. A., Omar, A. H., Hu, Y., Powell, K. A., Liu, Z., Hunt, W. H., and Young, S. A.: Oberview of the CALIPSO mission and CALIOP data processing algorithms, J. Atmos. Ocean. Tech., 26, 2310-2323, doi:10.1175/2009JTECHA1281.1, 2009.

Wohltmann, I., Lehmann, R., and Rex, M.: The Lagrangian chemistry and transport model ATLAS: simulation and validation of stratospheric chemistry and ozone loss in the winter 1999/2000, Geosci. Model Dev., 3, 585-601, doi:10.5194/gmd-3-585-2010, 2010.

Wohltmann, I., Wegner, T., Müller, R., Lehmann, R., Rex, M., Manney, G. L., Santee, M. L., Bernath, P., Sumińska-Ebersoldt, O., Stroh, F., von Hobe, M., Volk, C. M., Hösen, E., Ravegnani, F., Ulanovsky, A., and Yushkov, V.: Uncertainties in modelling heterogeneous chemistry and Arctic ozone depletion in the winter 2009/2010, Atmos. Chem. Phys., 13, 3909-3929, doi:10.5194/acp-13-3909-2013, 2013. 